ROGÉRIO DE ALMEIDA GERALDINO

UTILIZAÇÃO DE RECURSOS DA TELEODONTOLOGIA NO ATENDIMENTO AOS TRAUMATISMOS DENTÁRIOS 


\section{UNIVERSIDADE DE BRASÍLIA \\ FACULDADE DE CIÊNCIAS DA SAÚDE \\ PROGRAMA DE PÓS-GRADUAÇÃO EM CIÊNCIAS DA SAÚDE}

ROGÉRIO DE ALMEIDA GERALDINO

UTILIZAÇÃO DE RECURSOS DA TELEODONTOLOGIA NO ATENDIMENTO AOS TRAUMATISMOS DENTÁRIOS

Dissertação apresentada como requisito parcial para a obtenção do Título de Mestre em Ciências da Saúde pelo Programa de Pós-Graduação em Ciências da Saúde da Universidade de Brasília.

Orientador: Prof. Dr. Júlio César Franco Almeida

Coorientadora: Prof. ${ }^{\underline{a}}$ Dr..$^{\underline{a}}$ Liliana Vicente Melo de Lucas Rezende 


\title{
UTILIZAÇÃO DE RECURSOS DA TELEODONTOLOGIA NO ATENDIMENTO AOS TRAUMATISMOS DENTÁRIOS
}

\begin{abstract}
Dissertação apresentada como requisito parcial para a obtenção do Título de Mestre em Ciências da Saúde pelo Programa de Pós-Graduação em Ciências da Saúde da Universidade de Brasília
\end{abstract}

Aprovado em

BANCA EXAMINADORA

\author{
JÚLIO CÉSAR FRANCO ALMEIDA - (Presidente) \\ UNB - BRASÍLIA - DF
}

SORAYA COELHO LEAL

UNB - BRASÍLIA - DF

CARLOS ALBERTO FELDENS

ULBRA - CANOAS - RS 
Dedico este trabalho ao desejo de ir além e à busca dos meios para realização dos sonhos 


\section{AGRADECIMENTOS}

A Deus pelas infinitas bênçãos que permite em minha vida.

À minha amada esposa, Patrícia Verena, e ao meu tesouro de filha, Izabella, pela compreensão e apoio nessa árdua mas engrandecedora caminhada.

Aos meus pais, Germano e Sônia, por terem me criado com valores nobres e pelo amor e apoio incondicionais que sempre me ofereceram.

Ao Todino, meu avô dentista, exemplo de amor à profissão, com suas lições de vida que sempre me encantaram e motivaram.

À minha adorada Maneda, que já se foi, mas que está feliz onde quer que esteja ao ver o seu neto ir além.

Ao meu grande tio Raulê, exemplo profissional, que me orientou para o acolhimento e atendimento infantil.

À minha Equipe CABI do presente e do passado, Izabel, Welma, Thayanne, Eloisa, Ângela, Priscila, Edilene e Nair, por terem me ajudado a chegar até aqui.

Às minhas grandes parceiras, Dr. ${ }^{a}$ Adriana e Dr. ${ }^{a}$ Elaine, por compartilhar conhecimento, desejo pela excelência e principalmente suas amizades.

Às amigas queridas do grupo Odontopediatras $24 \mathrm{~h}$, Dr. ${ }^{a}$ Camila, Dr. ${ }^{\text {a }}$ Ludimila e Dr. ${ }^{\text {a }}$ Ana Alice, por compartilharem esse sonho comigo.

Ao meu amigo Gabriel por sua disponibilidade, paciência e competência profissional.

Aos amigos Dr. Edélcio e Dr. ${ }^{a}$ Patrícia pelo apoio e companheirismo.

Ao meu orientador Prof. Júlio César e minha coorientadora Prof. a Liliana Lucas por me permitirem conhecer o universo acadêmico.

À Prof. a Soraya, sempre tão solícita, por ter aceitado abrilhantar a banca examinadora deste trabalho.

Ao Prof. Feldens por me inspirar na realização deste trabalho e me dar a honra de aceitar compor minha banca.

Às minhas amigas e colaboradoras, Prof. ${ }^{a}$ Cibele e Prof. ${ }^{a}$ Amália, que realizaram as análises estatísticas.

À equipe do Projeto Trauma Dental do Hospital Universitário de Brasília.

Aos meus queridos pacientes e suas famílias por compartilharem emoções e me inspirarem a seguir na busca do conhecimento. 
"Você nunca sabe que resultados virão da sua ação. Mas se você não fizer nada, não existirão resultados" (Mahatma Gandhi) 


\section{RESUMO}

O objetivo geral deste estudo foi avaliar a utilização de recursos da Teleodontologia (TO) no atendimento aos Traumatismos Dentários (TD). Para atender ao objetivo geral dois estudos com objetivos específicos foram propostos: 1) Analisar a percepção e atitudes dos odontopediatras do Distrito Federal sobre o uso de ferramentas da TO no atendimento aos TD. 2) Comparar os níveis de concordância interexaminadores nos diagnósticos de TD realizados presencialmente e a distância por meio da utilização de fotografias digitais obtidas por meio de câmera fotográfica integrada a telefone celular. No estudo 1, utilizou-se um questionário aplicado online (http://pt.surveymonkey.com) com perguntas referentes à TO e TD a 37,16\% da população de odontopediatras do Distrito Federal $(n=97)$. Foram realizadas análises descritivas e teste de correlação de Pearson. No estudo 2, foram examinados 40 pacientes com 89 dentes traumatizados $(n=89)$. Diagnósticos presenciais e a distância utilizando-se imagens e imagens associadas a informações clínicas foram realizados por 7 examinadores e avaliada a concordância interexaminadores utilizando-se a medida AC1 de Gwet. No estudo 1, identificou-se que $80,41 \%$ dos entrevistados já tinham usado alguma ferramentas da TO na prática clínica e 76,29\% para diagnóstico e tratamento relacionados aos TD. Os resultados evidenciaram a utilização das ferramentas da TO com possibilidade de orientar pessoas leigas e profissionais a distância para o atendimento de TD. No estudo 2, a concordância média (AC1 de Gwet) obtida entre o Diagnóstico Presencial e o Diagnóstico a Distância foi "Muito Boa" para os casos utilizando apenas imagens ( 0,83 ou superior) e para os casos em que os dados clínicos foram associados às imagens $(0,93$ ou superior). A maioria dos odontopediatras do Distrito Federal, Brasil, já utilizam ferramentas da TO no atendimento aos casos de TD e tiveram percepções e atitudes positivas em relação a elas. Fotografias digitais obtidas por telefone celular são ferramentas eficazes no auxílio ao diagnóstico à distância em casos de TD. O diagnóstico à distância utilizando-se imagens é equivalente ao diagnóstico clínico presencial na maioria dos casos de TD.

Palavras-chave: Traumatismos Dentários, Odontopediatria, Teleodontologia. 


\begin{abstract}
The general objective of this study was to evaluate the use of resources of the Teledentistry (TD) in the management of Traumatic Dental Injuries (TDI). In order to comply with this objective, two studies with specific objectives were designed: 1) Evaluation of prevalence and exploration of perception and attitudes of pediatric dentists from Brazil's Distrito Federal towards the use of teledentistry in the management of TDI. 2) Comparison of agreement level among inter-examiners in the TDI diagnosis when performed presently or remotely, through the use of digital photographs, captured with a mobile phone camera. In the first study, an online questionnaire (http://pt.surveymonkey.com) was answered by $37.16 \%$ of the pediatric dentists in Distrito Federal $(n=97)$. Descriptive analyses and the Pearson correlation test were performed. In the second study, 40 patients with 89 traumatized teeth were examined $(n=89)$. Present and remote diagnosis, aided by images and images associated to clinical data, were performed by 7 examiners and the inter-examiners agreement was assessed with the Gwet's AC1 measure. In the first study, it was identified that $80.41 \%$ of participants had already used one of the TD tools in their clinical practice, and $76.29 \%$ for the diagnosis and treatment related to TDI. The results evidence the use of TD tools, with the possibility to remotely orientate laypersons and professionals as to appropriately take care of TDI. In the second study, the mean agreement obtained between the Present Diagnosis and the Distant Diagnosis was considered "Very Good" for cases in which only images were used ( 0.83 or superior) and for cases in which clinical data was associated to images ( 0.93 or superior). Most of the pediatric dentists from Brazil's Distrito Federal have already used TD tools in the management of TDI and have a positive perception and attitude towards them. Digital photographs, captured with a mobile phone camera, are effective tools for the distant diagnosis in cases of TDI. The distant diagnosis through images is equivalent to the present clinical diagnosis in most TDI cases.
\end{abstract}

Keywords: Traumatic Dental Injuries, Pediatric Dentistry, Teledentistry. 


\section{LISTA DE ILUSTRAÇÕES}

\section{Artigo 1}

Figura 1 - Assessment of correlation between factors "Perception towards the use of TD" and "Attitudes on the TD".... .28

\section{Artigo 2}

Figura 1 - Frontal (1-A), Occlusal (1-B) and in Occlusion (1-C) photographs. .40

Figura 2 - Categories of dental trauma and clinical characteristics. Adaptation from Di Angelis et al. and Malmgren et al.

Figura 3 - Joint analysis - Gwet's agreement profiles calculated among the examiners when only images were available and when both images and clinical data were available for analysis .45

Figura 4 - Joint analysis - Comparative boxplots for the agreement measures between examiners DD and the PD for each trauma category and tooth (except left superior canine and right superior canine), calculated for the diagnostics based on images . .46

Figura 5 - Joint analysis - Comparative boxplots for the agreement measures between examiners DD and the PD for each trauma category and tooth (except left superior canine and right superior canine), calculated for the diagnostics based on images and clinical data 


\section{LISTA DE TABELAS}

\section{Estudo 1}

Tabela 1 - Items 1-8 concerded pediatric dentists' demographic aspects and their experiences related to TD resources

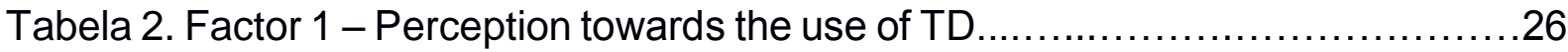

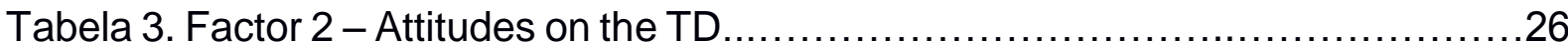

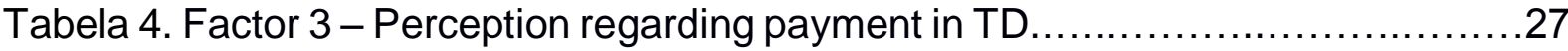

Tabela 5. Factor 4 - Application of TD for determining the severity of TDI............27

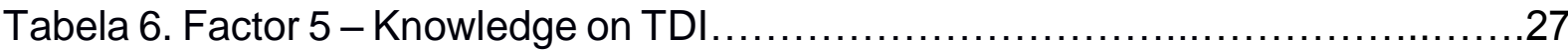

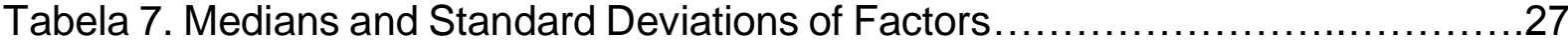



\section{Estudo 2}

Tabela 1- Distribution of total samples by different characteristics 43

Tabela 2- TDI Cases distribution 


\section{LISTA DE ABREVIATURAS E SIGLAS}

TO - Teleodontologia

TD - Traumatismo Dentário

RNTO - Rede Nacional de Teleodontologia

UERJ - Universidade Estadual do Rio de Janeiro

SUS - Sistema Único de Saúde

TDI - Traumatic Dental Injuries

TD - Teledentistry

CRO-DF - Conselho Regional de Odontologia - Distrito Federal

CFO - Conselho Federal de Odontologia

DP - Diagnóstico Presencial

DD - Diagnóstico a Distância

HUB - Hospital Universitário de Brasília 


\section{SUMÁRIO}

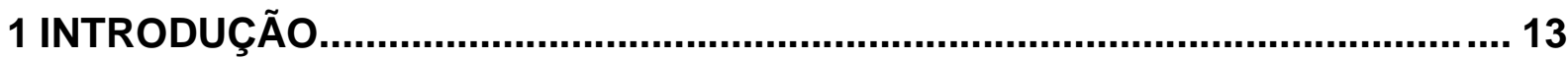

2 REVISÃO DA LITERATURA..........................................................................15

2.1 TRAUMATISMO DENTÁRIO COMO PROBLEMA DE SAÚDE PÚBLICA.............15

2.2 LIMITAÇÕES DO ATENDIMENTO AO TRAUMATISMO DENTÁRIO..................16

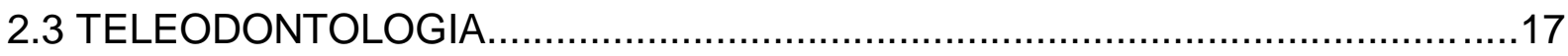

2.4 APLICAÇÃO DA TELEODONTOLOGIA NO ATENDIMENTO AO



3 OBJETIVOS

4 ARTIGO 1. PERCEPTION AND ATTITUDES OF PEDIATRIC DENTISTS TOWARDS THE USE OF TELEDENTISTRY TOOLS IN THE MANAGEMENT OF TRAUMATIC DENTAL INJURIES. .21

5 ARTIGO 2. DISTANT DIAGNOSIS OF TRAUMATIC DENTAL INJURIES USING DIGITAL PHOTOGRAPH CAPTURED WITH MOBILE PHONE...............................36

6 DISCUSSÃO

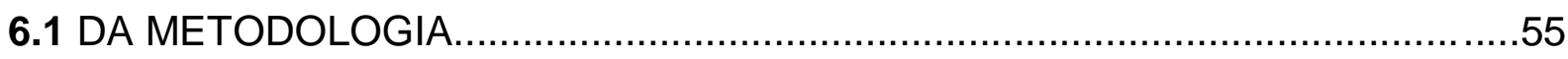





REFERÊNCIAS



ANEXOS 


\section{INTRODUÇÃO}

Acidentes são comuns em crianças e adolescentes, geralmente em decorrência de quedas e prática de esportes (1). Parte desses acidentes, os Traumatismos Dentários (TD), afetam os dentes permanentes e decíduos com incidência que varia de $1 \%$ a $3 \%$ (2) e prevalência entre $4 \%$ a $40 \%$ dependendo da população estudada (3). Os TD são mais comuns nos primeiros dez anos e tendem a diminuir ao longo da vida (4). O TD é considerado um problema de saúde pública (5). Suas consequências afetam a condição psicológica das pessoas acometidas, interferindo na qualidade de vida $(5,6)$ e bem estar social $(7)$.

A ocorrência de TD fora dos horários regulares de trabalho colabora para a dificuldade de se encontrar um Cirurgião Dentista $(8,9)$ para realizar o atendimento. Quando o profissional é encontrado, muitas vezes não possui conhecimento e capacitação necessários para o atendimento do $\operatorname{TD}(9,10,11)$. Em decorrência disso, o reparo das funções e estética lesionadas pelo TD pode gerar custos elevados, principalmente nos dentes permanentes, que tendem a se ampliar ao longo da vida $(9,12)$. Além dos custos diretos temos os custos indiretos, como o absenteísmo gerado pelo TD (9). Um atendimento adequado poderia tanto limitar os danos, quanto diminuir os custos relacionados aos traumas dentários.

Estudos na área de Teleodontologia (TO) sugerem que a consulta a distância pode contribuir no atendimento ao TD $(8,13)$. Em revisão sistemática avaliando a viabilidade da TO, Daniel et al. encontraram heterogeneidade nos delineamentos, métodos e resultados dos estudos, entretanto identificou-se uma tendência à eficácia e efetividade principalmente relacionados aos diagnósticos de alterações bucais (14). Em estudo realizado na Suíça, um centro de teleconsulta de saúde identificou que uma parcela significativa dos atendimentos realizados aconteceu em função dos TD (8). Park et al. (13) em um estudo in vitro constatou a possiblidade de o diagnóstico a distância por imagens ser realizado por aparelhos celulares com câmeras fotográficas integradas. De acordo com Feldens et al. (15) há uma escassez de estudos sobre avaliação de serviços e tecnologias no campo da traumatologia dentária. Mariño e Ghanim (16) sugerem que estudos sobre a TO sejam realizados em países em desenvolvimento. 
Diante desses problemas, buscou-se neste trabalho avaliar a prevalência e explorar a percepção e atitude dos odontopediatras do DF sobre a utilização de ferramentas da TO no atendimento ao TD. Buscou-se ainda comparar os níveis de concordância interexaminadores nos casos de diagnósticos realizados presencialmente e a distância, utilizando fotografias digitais realizadas por telefone celular em casos de TD. 


\section{REVISÃO DA LITERATURA}

\subsection{TRAUMATISMO DENTÁRIO COMO PROBLEMA DE SAÚDE PÚBLICA}

O TD é considerado um problema de saúde pública emergente $(17,18)$ devido ao crescente aumento dos níveis de violência, do número de acidentes de trânsito e da maior participação das crianças em atividades esportivas (19). O TD é também evidenciado pelo decréscimo da prevalência da doença cárie, o que permite um olhar ampliado para outras enfermidades bucais. As consequências do TD varia desde a simples fratura do esmalte até a avulsão dentária (20).

Estudos epidemiológicos indicam que as taxas de prevalência desse importante agravo em saúde bucal variam de 4 a $40 \%$, dependendo da população estudada e causam grande impacto psicossocial nas pessoas acometidas $(3,21)$. Dados da Organização Mundial da Saúde consideram maior a prevalência de TD entre 16 a 40\% das crianças na faixa etária de 6-12 anos de idade (3). No Brasil, dados de um levantamento das condições de saúde bucal da população brasileira, incluindo prevalência de TD aos 12 anos de idade, revelaram uma média nacional de 20,5\% e de $18,9 \%$ no Distrito Federal (22).

Ramos-Jorge et al. (23) demonstraram a importância de incluir o atendimento ao TD como prioridade em programas de saúde pública, pois a falta de tratamento pode interferir negativamente na qualidade de vida de escolares, impactando na capacidade e prazer na alimentação e limitação da expressão do sorriso.

Por sua vez, Petersen (24) considerou os custos financeiros elevados nos cuidados imediatos e acompanhamento dos pacientes acometidos por TD. Os custos indiretos com os atendimentos de TD também são expressivos em relação aos custos totais (25). Por outro lado, considera-se que os custos em ações preventivas podem ser muito reduzidos, quando comparados ao tratamento curativo nos casos complicados de TD em dentes permanentes (9).

Ações e políticas podem ser desenvolvidas para a redução dos TD, especialmente nas escolas, incluindo a educação pessoal e social, estratégias contra 
a violência e bullying, adequação de ambientes físicos, políticas de saúde, políticas sobre o uso do álcool, fornecimento de equipamentos de proteção individual, como protetores bucais, e os vínculos com os serviços de saúde (26). Levin e Zadik (27) também reconheceram e enfatizaram que muitos casos de TD podem ser evitados com a adoção de estratégias que evitem os acidentes ou violência que originam o TD, bem como limitem o desenvolvimento e complicações da morbidade em decorrência destes.

\subsection{LIMITAÇÕES DO ATENDIMENTO AO TRAUMATISMO DENTÁRIO}

O TD é frequentemente imprevisível e a avaliação inicial e tratamento de urgência são essenciais para um bom prognóstico (13). Estudo realizado por Yeng e Parashos (10) identificou uma grave deficiência de informações sobre o conhecimento técnico, além de outras dificuldades para o tratamento do TD por dentistas em todo o mundo. De França et al. (11), confirmaram o baixo nível de conhecimento no atendimento ao TD por dentistas no Brasil.

Durante o atendimento de casos de TD no consultório, várias dificuldades são encontradas, dentre elas a limitação do conhecimento técnico e habilidades, custo elevado e disponibilidade de tempo dos profissionais (28). A indisponibilidade local de profissionais com as habilidades necessárias para os atendimentos em TD também é um problema de acesso com possibilidade de elevação dos custos financeiros (25).

Glendor et al. (9) consideram que nos casos de TD complicados em dentes permanentes, o tempo decorrido até o primeiro atendimento é essencial para o prognóstico, tornando o acesso ao serviço uma condição de grande importância. Entretanto, consideram altos os custos para a disponibilização de um serviço de nível elevado, especialmente em horários fora do expediente de trabalho.

Em função da alta prevalência, da repercussão na qualidade de vida, da dificuldade de acesso aos serviços de saúde, da necessidade de diagnóstico rápido e adequado, da limitação do conhecimento técnico dos dentistas acerca dos TD, identificou-se a TO como possível instrumento auxiliar na definição do diagnóstico e orientação para o tratamento dessas condições traumáticas $(8,13)$. 


\subsection{TELEODONTOLOGIA}

A TO pode ser definida como a prestação de serviços odontológicos a distância, por meio de orientações ou tratamento através da tecnologia da informação, substituindo o contato pessoal direto com o paciente envolvido. As aplicações da TO envolvem registros eletrônicos de pacientes, diagnósticos, sistemas de apoio à decisão clínica e educação do paciente (29).

São usados basicamente dois tipos principais de tecnologia na TO: (i) a síncrona ou videoconferência, onde são realizadas as consultas ao vivo, que são descritos como recursos mais dispendiosos, e (ii) a assíncrona, onde as imagens são armazenadas e transmitidas a outro profissional a distância (30).

Um dos maiores projetos de Teleodontologia já realizados teve início em 1994 e foi desenvolvido por dentistas das Forças Armadas dos EUA. Permitia a obtenção da opinião a distância de outros dentistas especialistas sobre a situação de pacientes. Os objetivos do projeto eram aumentar o acesso e a qualidade da assistência odontológica prestada aos pacientes, além de diminuir os seus custos, atingindo suas tropas e dependentes em todo o mundo (31).

Na década de 1990, as pesquisas foram principalmente nas áreas de cirurgia oral (32), estomatologia ou patologia oral (33), com a teleodontologia focada no telediagnóstico. Mais recentemente, a odontopediatria foi incorporada à TO $(34,35)$, inclusive para casos de TD (36). A maioria das pesquisas tem sido realizadas nos EUA e na Europa, e pouco tem sido feito nos países em desenvolvimento (37).

Em um estudo-piloto examinando a confiabilidade e a precisão do diagnóstico de doenças da mucosa oral, com base em informações escritas, sem imagens visuais da lesão, concluiu-se que a acurácia diagnóstica foi moderada (38). Entretanto, Bradley et al. (30) sugerem a utilização da fotografia clínica como ferramenta de diagnóstico para os pacientes com doenças da mucosa oral, melhorando a precisão diagnóstica, como uma alternativa para a consulta presencial. 
A TO foi proposta para reduzir o custo global e proporcionar melhor atendimento aos pacientes em relação aos processos tradicionais, além de fornecer informações mais completas para análise de dados (31). Para Mariño e Ghanim (37), a verdadeira vantagem da TO reside na redução das desigualdades na saúde, por oferecer melhor acesso e cuidados mais justos nos serviços odontológicos especializados. $O$ fator mais citado em apoio à adoção da TO é o seu potencial como uma forma mais eficiente de prestação de serviços, porém ainda há pouca evidência para apoiar essa hipótese (30).

A TO é uma área em expansão, mas ainda existem algumas barreiras à sua utilização, principalmente ligadas às questões legais e éticas, tais como confidencialidade das informações odontológicas (39). Pesquisas adicionais são necessárias para avaliar as modalidades ideais, custos e os seus possíveis benefícios (37).

No Brasil, a Rede Nacional de Teleodontologia (RNTO), criada em 2011, congrega os Núcleos de TO do País e tem como objetivo estabelecer um espaço para a troca de experiências, compartilhamento de expertises e realizar parcerias. Dessa maneira a Saúde Bucal no Brasil amplia seu espaço em volume e atenção no espaço virtual, permitindo troca de informações, segunda opinião aos profissionais da rede pública e privada, formação continuada e permanente no serviço e alcance facilitado de todos os profissionais e estudantes do País (40).

Dentro dos núcleos de Telessaúde no Brasil, além do ensino a distância, um projeto da Universidade Estadual do Rio de Janeiro (UERJ) oferece o SIEDIS eDiagnóstico, uma ferramenta de diagnóstico a distância, exclusiva para médicos, dentistas e enfermeiros do SUS no Estado do Rio de Janeiro (41).

\subsection{APLICAÇÃO DA TELEODONTOLOGIA NO ATENDIMENTO AO TRAUMATISMO DENTÁRIO}

Segundo Bradley et al. (30), o uso de TO no manejo de pacientes com doenças da mucosa bucal pode funcionar com êxito. Desta forma, serviços de telemedicina se mostram úteis para casos relacionados ao TD e centros específicos 
de TO podem oferecem apoio quando um dentista não estiver acessível, incluindo chamadas de áreas rurais ou fora do horário de expediente (8).

O protocolo da Associação Internacional de Traumatologia Dentária sugere que diante dos casos de TD (avulsão dentária), pessoas leigas podem ser orientadas por telefone, ou por aplicativo desenvolvido para smartphones ou tablets, no local do acidente $(42,43)$.

Segundo Park et al. (44), imagens de telefones celulares são fáceis de serem obtidas e proporcionam boas informações para o diagnóstico inicial nos casos de TD. Em outro estudo de Park et al. (13), observou-se que a possibilidade de transferência de imagens para especialista com experiência pode aumentar a probabilidade de preservar os dentes em casos de TD. Os autores constataram ainda que a possibilidade de compartilhamento e qualidade das imagens durante uma teleconsulta são os fatores mais importantes para o sucesso dessa modalidade de atendimento. 


\section{OBJETIVOS}

3.2 OBJETIVO GERAL

Avaliar a utilização de recursos da TO no atendimento aos TD.

\subsection{OBJETIVOS ESPECÍFICOS}

3.3.1 Avaliar a Prevalência e Explorar a Percepção e Atitudes dos Odontopediatras do Distrito Federal, sobre o Uso de Ferramentas da TO no Atendimento dos TD.

3.3.2 Comparar os Níveis de Concordância Interexaminadores nos Diagnósticos de TD Realizados Presencialmente e a Distância Utilizando Fotografias Digitais Realizadas por Telefone Celular. 


\section{ARTIGO 1 - PERCEPTION AND ATTITUDES OF PEDIATRIC DENTISTS TOWARDS THE USE OF TELEDENTISTRY TOOLS IN THE MANAGEMENT OF TRAUMATIC DENTAL INJURIES}

Rogério de Almeida Geraldino, DDS, MsC student ${ }^{1}$

Liliana Vicente Melo de Lucas Rezende, DDS, MsC, $\mathrm{PhD}^{2}$

Cibele Queiroz da-Silva, $\mathrm{MsC}, \mathrm{PhD}^{3}$

Amalia Raquel Pérez-Nebra, $\mathrm{MsC}, \mathrm{PhD}^{4}$

Júlio César Franco Almeida, DDS, MsC, $\mathrm{PhD}^{5}$

${ }^{1}$ Health of Sciences Faculty, University of Brasília; CABI Odontologia - Private Clinic, Brazil.

${ }^{2}$ Dentistry Department, Health Sciences Faculty, University of Brasília, Brazil.

${ }^{3}$ Statistics Department, University of Brasília, Brazil.

${ }^{4}$ Psychology Department, Centro Universitário de Brasília, Brazil.

${ }^{5}$ Oral Health Unit - University Hospital, Health Sciences Faculty, University of Brasília, Brazil. 


\begin{abstract}
Background: The management of Traumatic Dental Injuries (TDI) is a challenge worldwide. The use of communication technologies by dentists makes of the Teledentistry (TD) a promising tool in the handling of TDI. Objective: The objective of this study was to evaluate the prevalence and to explore the perception and attitudes of pediatric dentists from Brazil's Distrito Federal (DF) towards the use of TD in the management of TDI. Material and Methods: In this analytical cross-sectional study, it was sent by e-mail to pediatric dentists registered in the DF Regional Dental Board $(\mathrm{n}=261)$ a semi-structured questionnaire, containing questions about their perception and attitudes towards TD and TDI. Responses scaling was based on Likert scale (5 completely agree, 4 - agree, 3 - neutral, 2 - disagree and 1 - completely disagree). Data were analyzed through descriptive statistics and Pearson correlation. Results: Responses were gathered in five factor groups: Perception towards the use of TD (4.11 \pm 0.54$)$, Attitude on the TD (4.20 \pm 0.55$)$, Perception regarding payment in TD (2.69 \pm 0.79$)$, Application of TD for determining severity in TDI (2.83 \pm 0.82$)$ and Knowledge on the TDI (3.94 \pm 0.68$)$. A moderate correlation between "Perception towards the use of TD" and "Attitude on the TD" was identified $(r=0.51 ; p=0.00)$, although correlation among aspects such as quality, knowledge, substitution of direct consultation, possibility of aid, ethical aspects, financial investment, second opinion and first aid was evidenced. Conclusion: A considerable prevalence of the use of TD tools in the management of TDI and a positive correlation between the Perception and the Attitude towards the use of such tools was confirmed in this study. The possibility of remote orientation of laypersons and professionals in the management of TDI was observed. Additional studies are important to evaluate the reliability of the TD in the diagnosis and treatment of TDI.
\end{abstract}

Key-words: Teledentistry; Traumatic Dental Injuries; Pediatric dentists; 


\section{Introduction}

Traumatic Dental Injuries (TDI) are frequently consequence of accidents (1) and the correct urgency care is essential to a good prognosis (2). TDI is considered a public health issue, being the reason for the majority of clinical procedures in anterior teeth, even overcoming in prevalence the caries, a decreasing disease in some countries (3). The TDI prevalence varies between 5 and $30 \%$, depending on the studied population $(4,1)$. The last survey on Oral Health rendered in Brazil identified a national prevalence of $20.5 \%$ for TDI, considering the 12-year-old population (5).

However, several limitations in the field of Dental Traumatology might be observed when it comes to the traditional means of assistance, such as the waiting time for treatment $(6)$, professional availability $(7,8)$, treatment costs $(9,10,11)$, lack of knowledge on the subject by dentists $(12,13)$, patients $(14,18)$, teachers $(15,16)$ rescuers (17) and health professionals (2).

The Teledentistry (TD) is defined as the remote dental assistance, consisting of orientation or treatment only through information technology, obviating personal contact with the patient. The applications of the TD concern electronic patient records, diagnosis, support systems for clinical decision and patient's education (19). It may widen the access and the quality of dental assistance to patients and reduce costs (20). It increases patient's satisfaction, efficiency and production (21) and is capable of reducing social disparities (22). In a recent systematic review, it was identified that, in spite of a methodological heterogeneity within the studies, there is a consistent tendency of support to the efficacy and effectiveness of the TD (23).

The growing access and improving quality of telecommunication means, the use of internet through smartphones, notebooks and tablets (24) and the possibility of remote consultations $(25,26)$ and of diagnosis by the use of images registered through built-in photographic cameras of mobile phones (6) expand the possibilities of TD application in the treatment of TDI (19).

The present study aimed to evaluate the prevalence and to explore the perception and attitudes of pediatric dentists from Brazil's Distrito Federal (DF) towards the use of TD in the management of TDI. 


\section{Material and methods}

This study was submitted and approved by the Committee of Ethics in Research at the Health Sciences Faculty, University of Brasília (Protocol number 713602). It was designed as an observational analytical cross-sectional study and performed using semi-structured questionnaires.

\section{Participants}

The inclusion criterion was subjected to dentists specialized in pediatric dentistry, registered in the Distrito Federal Regional Dental Board (CRO-DF) until May 9th, 2014, and who had an e-mail address. Out of the 281 registered pediatric dentists, only 261 e-mails were confirmed, which corresponded to $92.55 \%$ of the total registered pediatric dentists. Specialists in Pediatric Dentistry were chosen to be the subjects of this study because the 0 -12-year-old age group is the most commonly stricken by TDI (27).

\section{Questionnaire}

The professionals received by e-mail an invitation with information about the research content, the Informed Consent Form and the link to access the questionnaire.

The online platform SurveyMonkey (http://pt.surveymonkey.com) was used to collect data. The validation was performed by five pediatric dentists and a psychologist. The responses of items 9 to 30 were scaled according to Likert's model, in an amplitude of 5-1 (5 - completely agree, 4 - agree, 3 - neutral, 2 - disagree and 1 completely disagree).

The questionnaire consisted of thirty questions. The five first concerned demographic information and the following twenty-five had as aim identifying the experience, perception and attitudes of pediatric dentists towards the use of TD in their daily clinical practice, in relation to costs, ethics, payment and technology skills, especially in the treatment of TDI.

\section{Statistical analysis}

An exploratory analysis of factor reduction was performed in 22 items from the questionnaire (Appendix B), with responses based on the Likert model. The factor reduction criterion was oblique rotation. For the correlation analysis, questionnaire variables were grouped in five different factors: Perception towards the use of TD; 
Attitudes on the TD; Perception regarding payment in TD; Application of TD determining the severity of TDI; Knowledge on TDI. Post-hoc Pearson correlation test, using the software SPSS 20 (SPSS Inc. Chicago. IL. USA), and descriptive statistics were performed.

\section{Results}

From the 261 invitations and questionnaires sent by e-mail, 97 were answered $(\mathrm{N}=97)$. The survey had a response rate of $37.16 \%$. The sample was representative, and a range error of $10 \%$ was considered.

The results were organized accordingly to descriptive analysis parameters, presenting information on: dentists' demographic characteristics and their experiences related to TD (Table 1); aspects such as quality, knowledge, substitution of direct consultation, possibility of aid, ethical aspects, financial investment, second opinion and first aid, all grouped in five factors (Tables 2-6); medians and standard deviations (Table 7); Pearson correlation between factors (Table 8).

Table 1. Items 1-8 concerned pediatric dentists' demographic aspects and their experiences related to TD resources Questionnaire Items

\begin{tabular}{|c|c|c|}
\hline \multicolumn{3}{|l|}{ 1. Age: (Years) } \\
\hline 2. Gender: & $\begin{array}{l}\text { Male } \\
6.19 \%\end{array}$ & $\begin{array}{l}\text { Female } \\
93.81 \%\end{array}$ \\
\hline \multicolumn{3}{|l|}{ 3. Time since end of specialization course: (Years) } \\
\hline 4. Do you have a computer or a mobile phone with connection to the internet? & $\begin{array}{c}\text { Yes } \\
100 \%\end{array}$ & $\begin{array}{c}\text { No } \\
0.00 \%\end{array}$ \\
\hline \multicolumn{3}{|l|}{ 5. Daily hours connected to the internet: } \\
\hline $\begin{array}{l}\text { 6. Are you able to electronically send or receive images and text and voice messages, fundamental } \\
\text { resources for practicing the teledentistry? }\end{array}$ & $\begin{array}{c}\text { Yes } \\
84.54 \%\end{array}$ & $\begin{array}{c}\text { No } \\
15.46 \%\end{array}$ \\
\hline $\begin{array}{l}\text { 7. Have you ever received phone calls, e-mails, SMS, MMS, video calls or messages in social } \\
\text { networks in which orientations related to dentistry were requested of you? }\end{array}$ & $\begin{array}{c}\text { Yes } \\
80.41 \%\end{array}$ & $\begin{array}{c}\text { No } \\
19.59 \%\end{array}$ \\
\hline $\begin{array}{l}\text { 8. Have you ever received phone calls, e-mails, SMS, MMS, video calls or messages in social } \\
\text { networks in which orientations concerning dental trauma (concussion, sub-luxation, luxation, } \\
\text { avulsion, dental fracture) were requested of you? }\end{array}$ & $\begin{array}{c}\text { Yes } \\
76.29 \%\end{array}$ & $\begin{array}{c}\text { No } \\
23.71 \%\end{array}$ \\
\hline
\end{tabular}

In terms of demography, 91 pediatric dentists (93.81\%) were female. The age varied from 26 to 71 , with the median age of 41 years. When considered the period since the end of specialization course, distribution varied from 2 to 33 years, with a median of 14 years, having $52.57 \%$ of the participants 11 to 20 years of specialized practice as pediatric dentists. The participants had a median 4-hour daily access to the internet. 
In relation to knowledge on TD and experience with its practice and tools, it was observed that $84.54 \%$ of the professionals had the required skills to send and receive images, text and voice messages; $80.41 \%$ had already used such resources for professional purposes and $76.29 \%$ had used them specifically while dealing with TDI.

The data shown in these preliminary analyses suggest that there is a latent element in perception and evaluation, provided that the items showing correspondence are related to the same issue. In this sense, a factorization of 22 questions was performed. The factorability analyses suggested six factors with Eigen values over 1 , although one of them did not reach $3 \%$ of the explained variance and was not considered $(28,29)$. In this regard, responses were gathered in five factors (Tables 2$6)$.

Table 2. Factor 1 - Perception towards the use of TD. Items 9, 13, 15, 25, 26, 29 and 30 concerned aspects of quality, knowledge, substitution of direct consultation and aid and ethics

\begin{tabular}{l|c|c|c|c|c}
\hline Questionnaire Items & $\begin{array}{c}\text { Strongly } \\
\text { agree }\end{array}$ & Agree & Neutral & Disagree & $\begin{array}{c}\text { Strongly } \\
\text { disagree }\end{array}$ \\
\hline $\begin{array}{l}\text { 9. The use of images (photos or videos) associated to } \\
\text { descriptive texts or voice messages improves the } \\
\text { comprehension of information shared through teledentistry. }\end{array}$ & $59.79 \%$ & $38.14 \%$ & $2.06 \%$ & $0.00 \%$ & $0.00 \%$ \\
\hline $\begin{array}{l}\text { 13. It is possible to share images and information with other } \\
\text { professionals, having as objective improving the diagnosis, } \\
\text { treatment and prognosis in cases of dental trauma. }\end{array}$ & $62.50 \%$ & $35.42 \%$ & $2.08 \%$ & $0.00 \%$ & $0.00 \%$ \\
\hline $\begin{array}{l}\text { 15. When text messages, images and videos are sent by } \\
\text { patients as means of distant consultation, these data must be } \\
\text { considered confidential. }\end{array}$ & $54.64 \%$ & $39.18 \%$ & $6.19 \%$ & $0.00 \%$ & $0.00 \%$ \\
\hline $\begin{array}{l}\text { 26. Distant consultation might in some cases substitute the direct } \\
\text { consultation for diagnosis, treatment or control in cases of dental } \\
\text { trauma. }\end{array}$ & $13.40 \%$ & $31.96 \%$ & $4.12 \%$ & $37.11 \%$ & $13.40 \%$ \\
\hline $\begin{array}{l}\text { 29. A call center might help patients and professionals in cases } \\
\text { of dental trauma. }\end{array}$ & $37.11 \%$ & $46.39 \%$ & $11.34 \%$ & $5.15 \%$ & $0.00 \%$ \\
\hline $\begin{array}{l}\text { 30. Based on the presented description of Teledentistry and on } \\
\text { its current practice, one might consider you a professional who } \\
\text { makes use of the tools teledentistry has to offer. }\end{array}$ & $24.74 \%$ & $51.55 \%$ & $11.34 \%$ & $11.34 \%$ & $1.03 \%$ \\
\hline
\end{tabular}

Table 3. Factor 2 - Attitudes on the TD. Items 9, 13, 15, 25, 26, 29 and 30 concerned aspects of quality, knowledge, substitution of direct consultation and aid and ethics

\begin{tabular}{l|c|c|c|c|c}
\hline Questionnaire Items & $\begin{array}{c}\text { Strongly } \\
\text { agree }\end{array}$ & Agree & Neutral & Disagree & $\begin{array}{c}\text { Strongly } \\
\text { disagree }\end{array}$ \\
\hline $\begin{array}{l}\text { 10. The financial investment in technological resources } \\
\text { necessary for the practice of teledentistry precludes its practice. }\end{array}$ & $4.12 \%$ & $10.31 \%$ & $27.84 \%$ & $39.18 \%$ & $18.56 \%$ \\
\hline $\begin{array}{l}\text { 11. It is possible to remotely orientate laypersons on how to } \\
\text { perform first aid in cases of dental trauma }\end{array}$ & $52.58 \%$ & $47.42 \%$ & $0.00 \%$ & $0.00 \%$ & $0.00 \%$ \\
\hline $\begin{array}{l}\text { 12. Remotely orienting layperson on how to perform first aid in } \\
\text { cases of dental trauma implicates in an infraction to the code of } \\
\text { ethics in dentistry. }\end{array}$ & $40.21 \%$ & $38.14 \%$ & $14.43 \%$ & $5.15 \%$ & $2.06 \%$ \\
\hline $\begin{array}{l}\text { 14. Sharing images and information with other professionals, } \\
\text { having as objective improving the diagnosis, treatment and } \\
\text { prognosis in cases of dental trauma, implicates in an infraction to } \\
\text { the code of ethics in dentistry. }\end{array}$ & $37.89 \%$ & $40.00 \%$ & $16.84 \%$ & $3.16 \%$ & $2.11 \%$ \\
\hline $\begin{array}{l}\text { 16. Less experienced professionals, when remotely oriented by } \\
\text { more experienced professionals, might execute more adequate } \\
\text { procedures in cases of dental trauma. }\end{array}$ & $45.36 \%$ & $51.55 \%$ & $2.06 \%$ & $1.03 \%$ & $0.00 \%$ \\
\hline
\end{tabular}


28. During a distant consultation, basic information should be given to the consulted professional, so that he/she may adequately orientate the patient, according to the conditions of the suffered dental trauma.

\begin{tabular}{|l|l|l|l|l}
\hline $58.33 \%$ & $37.50 \%$ & $4.17 \%$ & $0.00 \%$ & $0.00 \%$ \\
& & & & \\
\hline
\end{tabular}

Table 4. Factor 3 - Perception regarding payment in TD. Items 22, 23 and 24 concerned payment by patients or other professionals and its possible interferences on information

\begin{tabular}{l|c|c|c|c|c}
\hline Questionnaire Items & $\begin{array}{c}\text { Strongly } \\
\text { agree }\end{array}$ & Agree & Neutral & Disagree & $\begin{array}{c}\text { Strongly } \\
\text { disagree }\end{array}$ \\
\hline $\begin{array}{l}\text { 22. Professionals should be paid by patients for distant } \\
\text { consultation and orientation. }\end{array}$ & $17.53 \%$ & $31.96 \%$ & $27.84 \%$ & $18.56 \%$ & $4.12 \%$ \\
\hline $\begin{array}{l}\text { 23. Professionals should be paid by other professionals for } \\
\text { distant consultation and orientation. }\end{array}$ & $5.15 \%$ & $11.34 \%$ & $32.99 \%$ & $37.11 \%$ & $13.40 \%$ \\
\hline $\begin{array}{l}\text { 24. Being paid for distant orientation in cases of dental trauma } \\
\text { interferes with the quality and quantity of information provided by } \\
\text { the professional. }\end{array}$ & $1.04 \%$ & $8.33 \%$ & $13.54 \%$ & $55.21 \%$ & $21.88 \%$ \\
\hline
\end{tabular}

Table 5. Factor 4 - Application of TD for determining the severity of TDI. Items 20 and 21 concerned the use of images and clinical data to evaluate the severity of the TDI

\begin{tabular}{l|c|c|c|c|c}
\hline Questionnaire Items & $\begin{array}{c}\text { Strongly } \\
\text { agree }\end{array}$ & Agree & Neutral & Disagree & $\begin{array}{c}\text { Strongly } \\
\text { disagree }\end{array}$ \\
\hline $\begin{array}{l}\text { 20. It is possible to evaluate the severity of a dental trauma } \\
\text { exclusively with images. }\end{array}$ & $3.09 \%$ & $7.22 \%$ & $10.31 \%$ & $58.76 \%$ & $20.62 \%$ \\
\hline $\begin{array}{l}21 . \text { It is possible to evaluate the severity of a dental trauma with } \\
\text { images associated to descriptive texts or voice messages. }\end{array}$ & $13.54 \%$ & $52.08 \%$ & $14.58 \%$ & $16.67 \%$ & $3.13 \%$ \\
\hline
\end{tabular}

Table 6. Factor 5 - Knowledge on TDI. Items 17, 18, and 19 concerned the need of the professional's physical presence for the diagnosis, the need for clinical procedures and the importance of time after the occurrence of TDI

\begin{tabular}{l|r|r|r|r|r}
\hline Questionnaire Items & $\begin{array}{l}\text { Strongly } \\
\text { agree }\end{array}$ & Agree & Neutral & Disagree & $\begin{array}{r}\text { Strongly } \\
\text { disagree }\end{array}$ \\
\hline $\begin{array}{l}\text { 17. In cases of dental trauma, a direct (present) clinical } \\
\text { evaluation made by the dentist is fundamental to the } \\
\text { establishment of a correct diagnosis. }\end{array}$ & $31.96 \%$ & $46.39 \%$ & $6.19 \%$ & $15.46 \%$ & $0.00 \%$ \\
\hline $\begin{array}{l}\text { 18. In cases of dental trauma, the time lapsed from its } \\
\text { occurrence to the first care is of utmost importance. }\end{array}$ & $78.35 \%$ & $18.56 \%$ & $2.06 \%$ & $1.03 \%$ & $0.00 \%$ \\
\hline $\begin{array}{l}\text { 19. In cases of dental trauma, clinical procedures performed by } \\
\text { the dentist are always necessary. }\end{array}$ & $25.77 \%$ & $21.65 \%$ & $8.25 \%$ & $35.05 \%$ & $9.28 \%$ \\
\hline $\begin{array}{l}\text { 27. }{ }^{*} \text { A considerable technical/scientific knowledge on several } \\
\text { dental specialties is necessary for treating dental trauma. }\end{array}$ & $27.84 \%$ & $49.48 \%$ & $8.25 \%$ & $13.40 \%$ & $1.03 \%$ \\
\hline
\end{tabular}

* The responses for item 27 were gathered in a sixth factor group. However, given the thematic similarities, they were kept in factor group 5.

Based on the levels of agreement settled by the Likert scale, medians (presented decreasingly) and standard deviations might be observed in Table 7.

Table 7. Medians and Standard Deviations of Factors,

\begin{tabular}{l|c|c}
\multicolumn{1}{c|}{ Factors } & Median & Std. Deviation \\
\hline Attitude in relation to the TD & 4.16 & 0.55 \\
\hline Perception towards the use of TD & 4.14 & 0.54 \\
\hline Knowledge on TDI & 4.00 & 0.68 \\
\hline $\begin{array}{l}\text { Application of TD for determining the severity of } \\
\text { TDI }\end{array}$ & 3.00 & 0.82 \\
\hline Perception regarding payment in TD & 2.66 & 0.79 \\
\hline
\end{tabular}


It is possible to verify that the factor Attitude on the TD has the most intense agreement rate among participants, with the smallest response variation. The factor Perception regarding payment in TD has the smallest agreement rate and the most considerable response variation.

\section{Multivariable Analysis}

A moderate correlation between factors Perception toward the use of TD and Attitudes on the TD was observed as a result of the multivariable analysis $(r=0.51$; $\mathrm{p}=0.00$ ) (Table 8). This correlation is graphically represented in Figure 1.

Table 8. Pearson correlation among factors $(r)$

\begin{tabular}{l|c|c|c|c}
\hline & $\begin{array}{c}\text { Attitude in relation } \\
\text { to the TD }\end{array}$ & $\begin{array}{c}\text { Perception regarding } \\
\text { payment in TD }\end{array}$ & $\begin{array}{c}\text { Application of TD for } \\
\text { determining the } \\
\text { severity of TDI }\end{array}$ & Knowledge on TDI \\
\hline $\begin{array}{l}\text { Perception towards } \\
\text { the use of TD }\end{array}$ & $0.517^{* *}$ & -0.15 & 0.18 & -0.08 \\
\hline $\begin{array}{l}\text { Attitude in relation to } \\
\text { the TD }\end{array}$ & $-0.27^{* *}$ & 0.00 & 0.06 \\
\hline $\begin{array}{l}\text { Perception regarding } \\
\text { payment in TD }\end{array}$ & & 0.06 & 0.07 \\
\hline $\begin{array}{l}\text { Application of TD for } \\
\text { determining the } \\
\text { severity of TDI }\end{array}$ & & & 0.00 \\
${ }^{* *}$ Correlation with $\mathrm{p}>0.01$ & & & \\
\hline
\end{tabular}

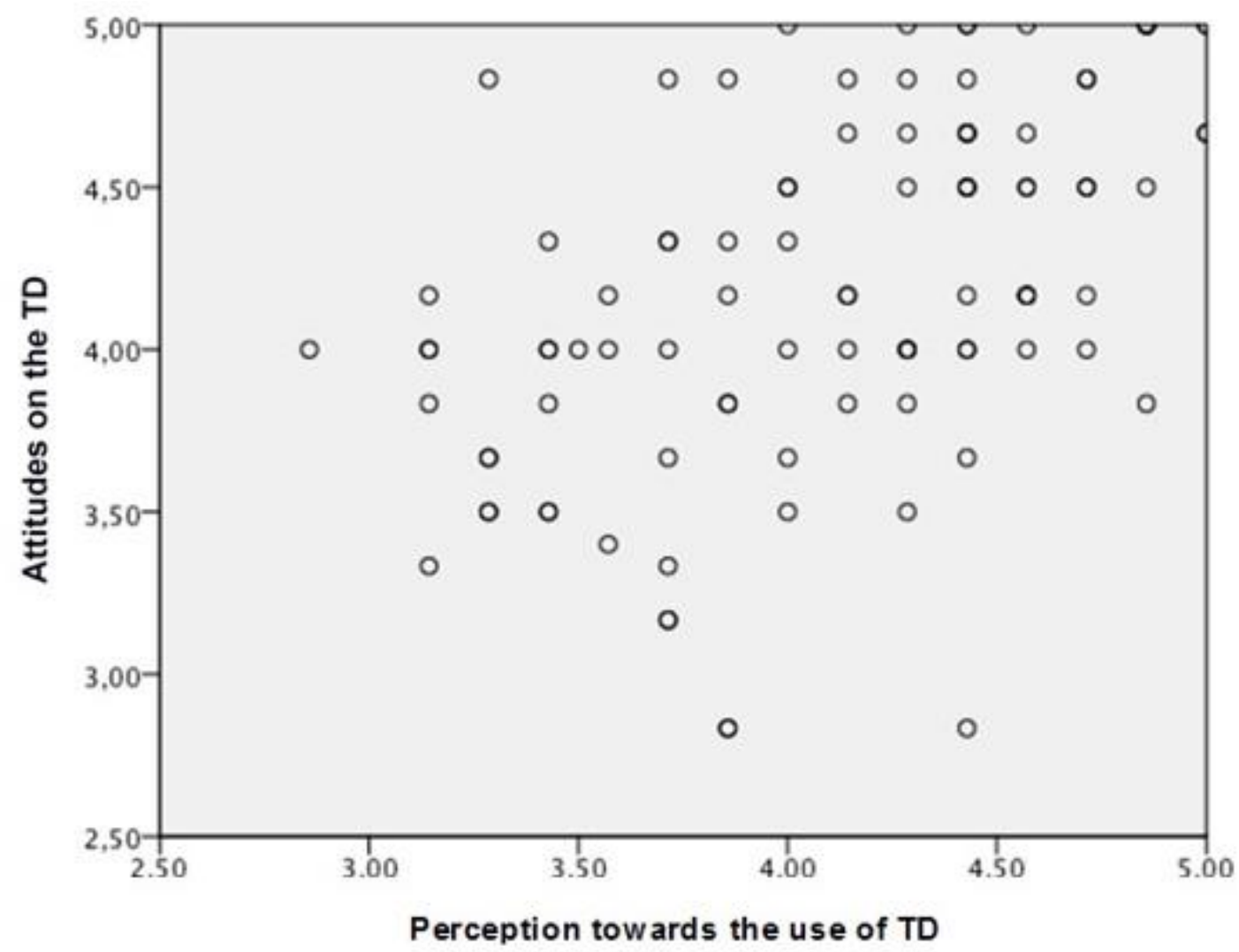

Figure 1. Assessment of correlation between factors "Perception towards the use of TD" and "Attitudes on the TD". 
No other correlation was identified between other factors, demographic conditions or experience on the use of TD.

\section{Discussion}

In general, it is accepted that there are important limitations to taking proper care in TDI, and to its prognostic are the professional competency and availability closely related (8). In this sense, the TD offers some resources that tend to minimize these problems (30).

Considering the study limitations, an information bias might be observed, given that the survey was conducted through internet, being assumed that the participants had sufficient knowledge and developed skills on operating technological devices. Such skills are fundamental to the practice of the TD and were investigated in this study.

Analyzing the factors Perception towards the use of TD (Median=4.14/SD=0.54) and Attitudes on the TD (Median=4.16/SD=0.55), with high levels of agreement among the participants, the correlation among aspects such as quality, knowledge, substitution of direct consultation, possibility of aid, ethical aspects, financial investment, second opinion and first aid was evidenced. This correlation suggests that a positive perception of pediatric dentists towards the TD tools may possibly stimulate its use or that its use favors this perception.

These correlations might be observed in associations that suggests that most participants believe remotely orienting laypersons on how to perform first aid in cases of TDI does not contravene the code of ethics in dentistry, but that data received in the remote consultation must be considered confidential. It is also evident when it is verified that most of the participants believe professionals may be remotely oriented by specialists or call centers while dealing with cases of TDI, or even when they consider themselves professionals who use the TD tools and believe it is possible to remotely orientate laypersons in cases of TDI.

The preoccupation with ethical aspects in relation to the confidentiality of data received from patients while treating a TDI, stated by most of the participants (93.82\%), was confirmed in a study that evaluated the use and attitudes of Finnish dentists (32). 
It also identified the lack of information on how to use safely the TD tools as one of the main problems.

Nevertheless, the majority of the participants (77.89\%) agreed that they might share images and information with other professionals without contravening the code of ethics in dentistry. This condition is comprehensively justified, granted that, although there is no formal regulation concerning the TD by the National Dental Board, it is already in use by professionals of the Brazilian National Public Health System, supported by training institutions (26).

The costs related to equipment were not considered an obstacle to the practice of the TD to most of the participants (57.74\%), what might be justified by the ever spreading popularization of telecommunication devices, smartphones, tablets and notebooks with access to the internet (24) and by the fact that all participants had access to the internet. In this point, our study differed from the one conducted by Flores-Mir et al. (2006), in which the costs with technological devices were considered one of the major obstacles to the TD practice (21), even though the types of technological resources were not specified in that study. However, it must be regarded that the costs of such resources have been reducing along the past years.

A call center was considered by most of the participants $(85.50 \%)$ a feasible possibility of aid for patients and professionals in dealing with cases of TDI, which is confirmed in previous studies $(8,25)$.

Almost all participants (96.91\%) believed that more experienced professionals might orientate less experienced professionals in treating cases of TDI. This information becomes relevant when taken into consideration studies that identify serious deficiencies in technical knowledge on management of TDI by dentists worldwide $(12,13)$.

A substantial variation in responses concerning the factor Perception regarding payment in TD (Median=2.66/SD=0.79) was observed, suggesting that the participants were not sure if the professional should or should not be paid for the practice of the TD. Most of them (77.09\%), though, thought that the lack of payment would not interfere with the quantity and quality of information provided by the professional. According to Padilha (33), when consulting other professional, namely the second 
opinion, the quality and quantity of the provided information for the remote diagnosis may be uncertain. In a study conducted by Mandall et al. (34), the perception of English general clinicians towards the use of TD for referring patients with orthodontic needs was considered positive, although they were also uncertain on the matter of payment. In a literature review, Yeng and Parashos (12) determined that insufficient payment perception in management of TDI was considered an obstacle. In this current study, the observed disagreement concerning payment might be a demotivating condition for the practice of TD.

Evaluating the factor Application of TD for determining the severity in TDI, low levels of agreement among pediatric dentists (Median=3.00/SD=0.82) were observed. A few believed it is possible to evaluate the severity of the TDI exclusively with images $(10.31 \%)$, but this percentage raised $(65.62 \%)$ when these images were associated to texts or voice message.

Finally, concerning the factor "Knowledge on TDI", intermediary levels of agreement among participants were obtained (Median=4.00/SD=0.68). The majority of participants believed that for a correct diagnosis of TDI, a present clinical evaluation made by the dentist is crucial, even though they disagree when the need for clinical procedures is discussed. Nonetheless, the time lapsed from the occurrence of a TDI to the first care was considered of utmost importance. These data are significant since studies such as the one performed by Needleman et al. (2) consider that patients who suffer a TDI usually look for care in hospital emergency services, even though medical practitioners are not customarily prepared to deal with such cases. Ramos-Jorge et al. (35), in a study conducted with parents whose children suffered a TDI, observed that most of them did not even recognize the TDI in their children. It is important to consider that this information might be acquired through a remote consultation with capacitated professionals (25).

The results provided by this study evince the great potential of the use of TD for the management of TDI, identified in the possibility of remotely orienting laypersons and professionals. 


\section{Conclusion}

A considerable prevalence of the use of TD tools in the management of TDI and a positive correlation between the Perception and the Attitude towards the use of such tools was confirmed in this study. The possibility of remote orientation of laypersons and professionals in the management of TDI was observed. Additional studies are important to evaluate the reliability of the TD in the diagnosis and treatment of TDI.

\section{Conflict of interest}

None of the authors have a conflict of interest to report.

\section{References}

1. Schuch HS, Goettems ML, Correa MB, Torriani DD, Demarco FF. Prevalence and treatment demand after traumatic dental injury in South Brazilian schoolchildren. Dent Traumatol 2013;29:297-302.

2. Needleman HL, Stucenski K, Forbes PW, Chen Q, Stack AM. Massachusetts emergency departments' resources and physicians' knowledge of management of traumatic dental injuries. Dent Traumatol 2013;29:272-279.

3. Andreasen JO, Andreasen FM, Andersson L. Textbook and Color Atlas of traumatic injuries to the teeth, 4th edn. Oxford: Blackwell-Munksgaard; 2007.

4. Fakhruddin KS, Kawas SA. Prevalence and etiological factors related to dental injuries amongst 18-22-year-olds in United Arab Emirates. Dent traumatol 2010;26:388-392.

5. Ministério da Saúde. SB Brasil 2010 - Pesquisa Nacional de Saúde Bucal. Resultados Principais. Brasília: Departamento de Atenção Básica, Secretaria de Atenção Básica, Ministério da Saúde; 2011, p-24. Available at: http://dab.saude.gov.br/CNSB/sbbrasil/arquivos/projeto_sb2010_relatorio_final.pdf. 20150528

6. Wonse P, Hae-Na L, Jin-Sun J, Jung-Hoon K, Grace HL, Kee-Deog K. Optimal protocol for teleconsultation with a cellular phone for dentoalveolar trauma: an in-vitro study. Imaging Science in Dentistry 2012;42:71-75. 
7. Glendor U, Jonsson D, Halling A, Lindqvist K. Direct and indirect costs of dental trauma in Sweden: a 2-year prospective study of children and adolescents. Community dentistry and oral epidemiology 2001;29:150-160.

8. Alnaggar D, Andersson L. Emergency management of traumatic dental injuries in 42 countries. Dent Traumatol 2014;31:89-96.

9. Borum MK, Andreasen JO. Therapeutic and economic implications of traumatic dental injuries in Denmark: an estimate based on 7549 patients treated at a major trauma centre. International Journal of Paediatric Dentistry 2001;11:249-258.

10. Petersen PE. Priorities for research for oral health in the 21 st Century - the approach of the WHO Global Oral Health Programme. Community Dental Health 2005;22:71-74.

11. Wong FSL, Kolokotsa K. The cost of treating children and adolescents with injuries to their permanent incisors at a dental hospital in the United Kingdom. Dent Traumatol 2004;20:327-333.

12. Yeng $T$, Parashos $P$. Dentists' management of dental injuries and dental trauma in Australia: a review. Dent Traumatol 2008;24:268-271.

13. De França RI, Traebert J, De Lacerda JT. Brazilian dentists' knowledge regarding immediate treatment of traumatic dental injuries. Dent Traumatol 2007;23:287-290.

14. Zadik, Y. Oral trauma and dental emergency management recommendations of first-aid textbooks and manuals. Dent Traumatol 2007;23:304-306.

15. Feldens EG, Feldens CA, Kramer PF, Da Silva KG, Munari CC, Brei VA. Understanding school teacher's knowledge regarding dental trauma: a basis for future interventions. Dent Traumatol 2010;26:158-163.

16. Shamarao S, Jain J, Ajagannanavar SL, Haridas R, Tikare S, Kalappa AA. Knowledge and attitude regarding management of tooth avulsion injuries among school teachers in rural India. Journal of International Society of Preventive \& Community Dentistry 2014;4(Suppl 1), S44.

17. De Carvalho CL, Poi WR, Panzarini SR, Sonoda CK, Da Silveira RT, Manfrin TM. Knowledge of firefighters with special paramedic training of the emergency management of avulsed teeth. Dent Traumatol 2009;25:58-63.

18. Padma Reddy M, Mamtha B, Waghray S, Lavanya R, Kumar BR, Gandhi Babu DB. Knowlwdge and Awareness on Emergency Management of Avulsed Tooth among Patients Attending A Dental College, India. J Res Adv Dent 2015;4:133-140. 
19. Khan SA, Omar H. Teledentistry in Practice: Literature Review. Telemedicine and e-Health 2013;19:565-567.

20. Rocca MA et al. The evolution of a teledentistry system within the Department of Defense. Proc AMIA Symp 1999;921-924.

21. Flores-Mir C, Palmer NG, Northcott HC, Khurshed F, Major PW. Perceptions and attitudes of Canadian dentists toward digital and electronic technologies. JournalCanadian Dental Association 2006;72:243.

22. Mariño R, Ghanim A. Teledentistry: a systematic review of the literature. Journal of Telemedicine and Telecare 2013;1-5.

23. Daniel SJ, Lin W, Sajeesh K. Teledentistry: A Systematic Review of Clinical Outcomes, Utilization and Costs. American Dental Hygienists Association, 2013; 87:345-352.

24. Brasil. IBGE. Acesso à Internet e Posse de Telefone Móvel Celular para Uso Pessoal. PNAD 2011. Rio de Janeiro. Available at: ftp://ftp.ibge.gov.br/Acesso_a_internet_e_posse_celular/2011/PNAD_Inter_2011.pdf. 20150528.

25. Lieinert N, Zitzmann NU, Filippi A, Weiger R, Krastl G. Teledental consultations related to trauma in a Swiss telemedical center: a retrospective survey. Dent Traumatol 2010;26:223-227.

26. Brasil. Telessaúde Brasil Redes. SIEDIS e-Diagnóstico. Ferramenta exclusiva para médicos, dentistas e enfermeiros do SUS no Estado do Rio de Janeiro. Available at: http://www.telessaude.uerj.br/telediagnostico/. 20150528.

27. Guedes AO, Alencar AHG, Lopes LG, Pécora JD, Estrela CA. Retrospective study of traumatic dental injuries in a Brazilian dental urgency service. Braz Dent $\mathrm{J}$ 2010;21:153-157.

28. Pasquali Luiz. Instrumentos psicológicos: Manual prático de elaboração. Brasília: LabPAM; IBAP.1999.

29. Pasquali Luiz. Psicometria: Teoria dos testes na psicologia e na educação. Petrópolis: Vozes. 2003.

30. Mariño R, Manton D, Marwaha P, Hallet K, Clarke K. The Implementation of Teledentistry for Pediatric Patients. GLOBAL HEALTH 2014: The Third International Conference on Global Health Challenges. p.14-19. 
31. Nagarajappa R, Aapaliya P, Sharda AJ, Asawa K, Tak M, Pujara P, \& Bhanushali N. Teledentistry: Knowledge and Attitudes among Dentists in Udaipur, India. Oral Health Dent Management 2013;12:138-144.

32. Ignatius E, Mäkelä K. Use and Attitudes towards Teleconsultation in Dentistry. EHealth Telecommunication Systems and Networks 2013;2:9.

33. Padilha EZ, Da Silva FR, Pontes FS. Segunda opinião especializada educacional no Telessaúde Brasil: Uma revisão. Publ. UEPG Ci. Biol. Saúde 2013;19:39-46.

34. Mandall NA, Quereshi U, Harvey L. Teledentistry for screening new patient orthodontic referrals. Part 2: GDP perception of the referral system. British Dental Journal 2005;199:727-729.

35. Ramos-Jorge J, Paiva SM, Tataounoff J, Pordeus IA, Marques LS, Ramos-Jorge ML. Impact of treated/untreated traumatic dental injuries on quality of life among Brazilian schoolchildren. Dent Traumatol 2014;30:27-31. 


\section{ARTIGO 2 - DISTANT DIAGNOSIS OF TRAUMATIC DENTAL INJURIES USING DIGITAL PHOTOGRAPH CAPTURED WITH MOBILE PHONE}

Rogério de Almeida Geraldino, DDS, MsC student ${ }^{1}$

Liliana Vicente Melo de Lucas Rezende, DDS, MsC, $\mathrm{PhD}^{2}$

Cibele Queiroz da-Silva, $\mathrm{MsC}, \mathrm{PhD}^{3}$

Júlio César Franco Almeida, DDS, MsC, $\mathrm{PhD}^{4}$

${ }^{1}$ Health Sciences Faculty, University of Brasília; CABI Odontologia, Private Clinic, Brazil.

${ }^{2}$ Dentistry Department, Health Sciences Faculty, University of Brasília, Brazil.

${ }^{3}$ Statistics Department, University of Brasília, Brazil.

${ }^{4}$ Oral Health Unit - University Hospital, Health Sciences Faculty, University of Brasília, Brazil. 


\section{Abstract}

Aim: To evaluate the levels of inter-examiners agreement in cases of TDI, when regarded the Present Diagnosis (PD) and the Distant Diagnosis (DD). Material and methods: The sample included 40 patients, with 89 traumatized teeth, who sought aid in two dental clinics, one private and the other public, both references in the management of TDI in Brazil's Distrito Federal. The anamnesis and clinical examination data were registered in electronic forms and digital photographs were captured with a camera integrated to a mobile phone (Galaxy 5, Samsung, Manaus, Brazil); afterwards they were uploaded in a file sharing website (https://drive.google.com). The digital photographs were remotely analyzed by six examiners in two different situations. First, only the images were shared with the remote examiners, who after formulating their first diagnostic hypotheses, received information on the present examination and were asked to formulate their second diagnostic hypotheses. Those were compared to the PD, which was considered the gold standard. The data were analyzed with the Gwet's AC1 inter-examiners measure, aiming to evaluate the agreement between PD and DD. Results: Of the patients, $65 \%$ were male. $60 \%$ of the teeth were permanent. Levels of inter-examiners agreement were 0.83 or superior for comparisons between PD and DD, when diagnosis was formulated exclusively with images, and 0.93 or superior when clinical information was associated. Conclusion: The DD is comparable to the PD in most cases of TDI when formulated by calibrated professionals. The levels of inter-examiners agreement are higher when clinical data are associated to images. The use of images captured with mobile phones is an effective tool and may assist the distant diagnosis in cases of TDI.

Key words: Dental Trauma, Clinical Diagnosis, Distant Diagnosis, Teledentistry. 
Introduction

Traumatic Dental Injuries (TDI) are considered a public health issue. They are usually unexpected and will have to be directly or indirectly handled throughout the patient's life (1,2). Main causes are falls, car accidents and violence (3). The TDI have a high prevalence in the population (4), although they might be prevented through educative programs or mechanisms for individual protection, such as mouth guards (5). They might be associated to occlusal aspects, such as increased overjet $(6,7,8)$, obesity (9) and visual deficiencies (10). The occurrence of TDI in children negatively interferes with their quality of life and their families' $(11,12)$. For a correct diagnosis and better prognosis, the TDI must be properly treated within the first post-trauma hours. The professional availability and competency are important factors for the management of TDI in emergency services, and if they lack, it is negatively reflected in the treatment and prognosis $(13,14)$, which is aggravated in rural areas $(15)$.

In such context the Teledentistry (TD) presents itself, with its technological resources and possibility to reduce limitations in the management of TDI $(16,17,18,19,20)$. The TD might be defined as the remote dental assistance, without direct contact with the patient, and it is used for diagnosis and in support systems for clinical decisions (21). Basically, two main kinds of resources are used in TD: (i) the synchronous, in which the consultations happen live, or through videoconference, described as more expensive resources, and (ii) the asynchronous, in which images are stored and remotely transmitted to the professional (22). The TD was initially proposed to reduce costs and provide a better care for patients, when compared to the traditional processes (23).

Bradley et al. (22) suggested the use of clinical photographs as a tool for diagnosis of diseases in oral mucosa, improving diagnostic accuracy, as an alternative for present consultation (22). In studies which aimed to validate TD tools, being used digital photographs for the diagnosis of caries lesions $(24,25,26)$ and oral lesions $(27,28)$, the distant diagnosis was confirmed as a reliable alternative.

The TD is a field in expansion, though there are still some limitations to its application, especially when concerning legal and ethical matters, such as confidentiality (29). However, more research is necessary as to evaluate the ideal modalities, costs and possible benefits of the TD (30), as well as its dissemination 
through parts of the world other than the USA and Europe, where its practice seems to be concentrated (31).

Considering the necessity of new technologies and systems that reduce the limitations of the conventional management of the TDI (32), this study aimed to evaluate the levels of inter-examiners agreement in cases of TDI, when regarded the Present Diagnosis (PD) and the Distant Diagnosis (DD).

2. Material and methods

This study was submitted to and approved by the Committee of Ethics in Research at the Health Sciences Faculty, University of Brasília, under protocol number 713602.

\subsection{Sample Selection}

This study was designed with a non-random convenience sample. Forty patients who had suffered TDI were evaluated (between January 2014 and February 2015) at the dental clinic in the University Hospital of Brasília (HUB) and at the private clinic owned by the first researcher in this paper (R de $A G$ ), being all clinical consultations result of self-referral and independent of age. The choice of these two dental care units is justified by the fact that they represent a public and a private emergency service, both references in the management of TDI in Brazil's Distrito Federal.

The inclusion criteria were patients who suffered TDI, and whose trauma exclusively affected superior anterior teeth. These criteria were established based on studies that confirm superior anterior teeth as the most affected by TDI $(33,4)$.

For the calculation of sample size, the PowerBinary function in $R$ Package KappaSize was used (34), adjusted to an inter-examiners agreement study (35), being considered a minimum of 40 participants.

\subsection{Calibration}

The calibration of six pediatric dentists, the remote examiners, was performed through a five-hour long theoretical and practical training. An oral exposition of the criteria for clinical diagnosis (Figure 2) and exercises using images of TDI cases 
projected in a TV (Bravia, Sony Electronics, Manaus, Brazil), aiming to establish agreement among examiners, also constituted the training process.

\subsection{Sample obtainment}

Before any clinical examination and procedures, the patients who had suffered a TDI were informed of the research and invited to participate. If agreed, an Informed Consent Form, authorizing the use of their images for the research, was signed.

The present diagnosis in the 40 clinical cases, hereby mentioned as PD, were determined by a single examiner ( $R$ de $A G$ ) using the criteria described in Figure 2, before the complementary radiographic examinations. The present examiner took three photographs of each patient (Frontal, Occlusal and in Occlusion). The first photograph, with a Frontal view, registered the superior anterior region, capturing the image of canines, lateral and central incisors and areas of free and attached gingiva. The second photograph, with an Occlusal view, registered the same teeth in a occlusal incidence, reaching up to the anterior region of the palate, according to the protocol suggested by Park et al. (20). The third photograph was performed with the teeth in Occlusion (Figure 1). After clinical evaluation, photographic registration and radiographic examination, all patients received the appropriate treatment.
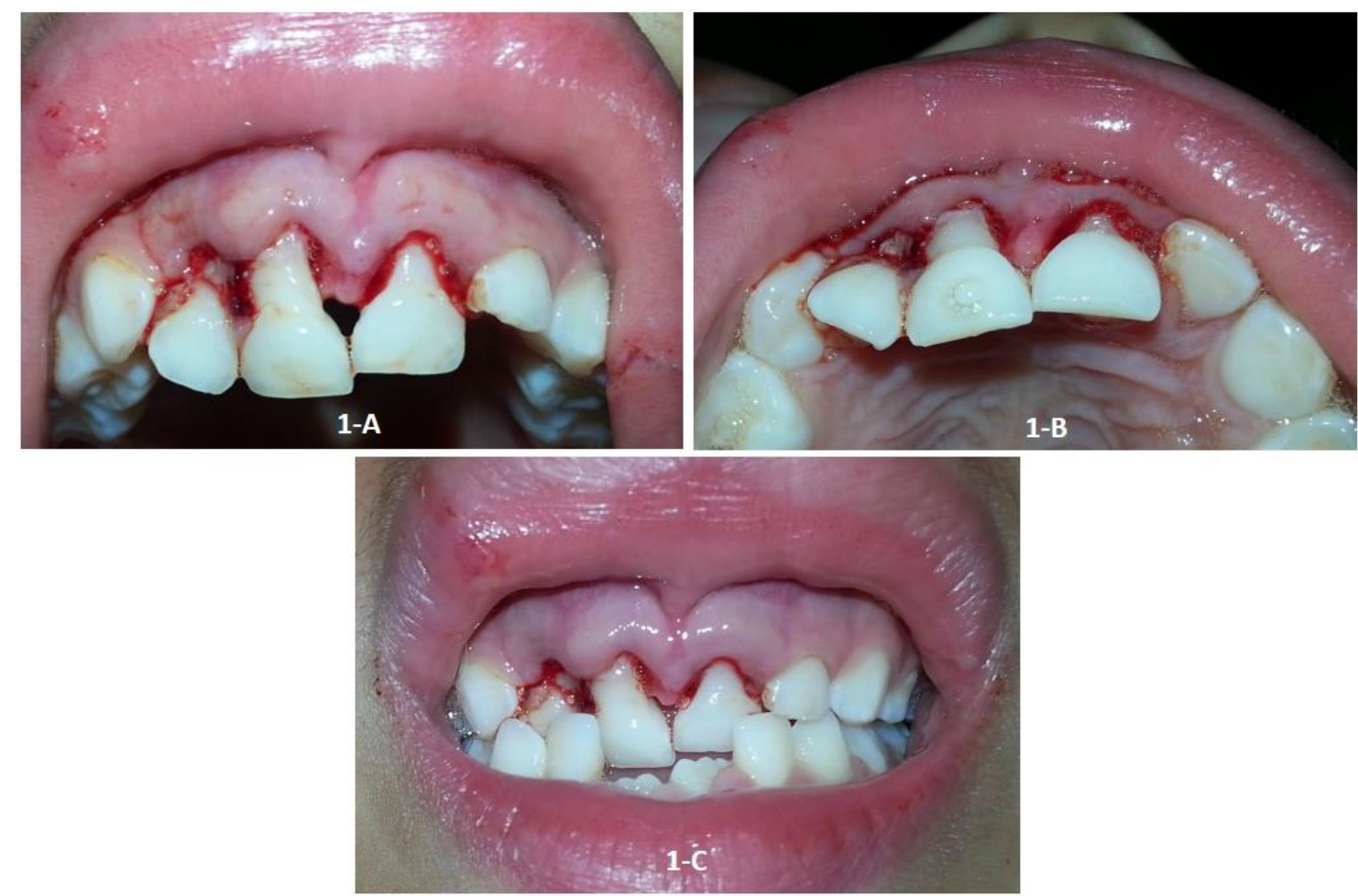

Fig. 1. Frontal (1-A), Occlusal (1-B) and in Occlusion (1-C) photographs. Clinical case in which Extrusive Luxation in teeth 52,51 and 61 were diagnosed in the present examination. 
The images were captured with a digital camera integrated to a cell phone which met the minimum requirements of 5 megapixels, Macro mode, autofocus, white balance function and flash (Galaxy 5, Samsung Electronics, Manaus, Brazil), according to the protocol proposed by Park et al. (20). No lips and cheeks retractors nor intraoral mirrors were used. The captured images were uploaded in a personal computer and stored in forty different files, one for each TDI case.

Afterwards the files containing the images and a form to be filled by the examiner for the DD were stored in a data-sharing website (https://drive.google.com). The six remote examiners were oriented thorough e-mail on how to access the files. They were also asked to inform, after thorough evaluation of the images, their diagnostic hypotheses for each clinical case in identified forms, which should be sent per e-mail to the main author ( $R$ de $A G)$.

The remote examiners formulated their diagnostic hypotheses, hereby mentioned as DD, for the 40 TDI cases, based in digital photographs captured during the present clinical examination (Frontal, Occlusal and in Occlusion). The "Frontal" image allowed verification of dental structures, color, dental vertical level, structure and gingival and adjacent tissues bleeding. The "Occlusal" image allowed the examiner to evaluate possible deviations along the dental axis and vestibular, palatal or lingual dislocations (20). Possible occlusal interferences could be observed with the "in Occlusion" (Figure 1).

After the DD were formulated exclusively with images, a new form containing clinical information about the cases was made available in each file in Google Drive. The examiners were contacted one more time and asked to fill the forms, now using the complementary clinical information to formulate the DD. Again, the forms were sent per e-mail to the main author.

Both the present examiner ( $R$ de $A G$ ) and remote examiners used the classification for TDI (Figure 2) suggested by Andreassen et al. (36):

\begin{tabular}{|l|l|l|}
\hline$N^{0}$ & Category of trauma & Clinical Features \\
\hline 1 & Concussion & $\begin{array}{l}\text { The tooth is tender to touch or tapping; it has not been displaced and does not have } \\
\text { increased mobility; Sensibility tests are likely to give positive results. }\end{array}$ \\
\hline 2 & Subluxation & $\begin{array}{l}\text { The tooth is tender to touch or tapping and has increased mobility; it has not been } \\
\text { displaced; Bleeding from gingival crevice may be noted; Sensibility testing may be } \\
\text { negative initially indicating transient pulpal damage. }\end{array}$ \\
\hline 3 & Lateral Luxation & $\begin{array}{l}\text { The tooth is displaced, usually in a palatal/lingual or labial direction; It will be immobile } \\
\text { and percussion usually gives a high, metallic (ankylotic) sound; Fracture of the alveolar }\end{array}$ \\
\hline
\end{tabular}




\begin{tabular}{|c|c|c|}
\hline & & $\begin{array}{l}\text { process present; Sensibility tests will likely give negative results; Occlusal } \\
\text { interferences might be present. }\end{array}$ \\
\hline 4 & Extrusive Luxation & $\begin{array}{l}\text { The tooth appears elongated and is excessively mobile; Sensibility tests will likely give } \\
\text { negative result. }\end{array}$ \\
\hline 5 & Intrusive Luxation & $\begin{array}{l}\text { The tooth is displaced axially into the alveolar bone; It is immobile, and percussion } \\
\text { may give a high, metallic (ankylotic) sound; Sensibility tests will likely give negative } \\
\text { results. }\end{array}$ \\
\hline 6 & Avulsion & The tooth is completely out of alveolus. \\
\hline 7 & Enamel Infraction & An incomplete fracture (crack) of the enamel without loss of tooth structure; Not tender. \\
\hline 8 & Enamel Fracture & $\begin{array}{l}\text { A complete fracture of the enamel with loss of structure; No visible sign of exposed } \\
\text { dentin; Not tender; Normal mobility; Sensibility pulp test usually positive. }\end{array}$ \\
\hline 9 & Enamel-Dentin Fracture & $\begin{array}{l}\text { A fracture confined to enamel and dentin with loss of tooth structure, but not exposing } \\
\text { the pulp; Percussion test: not tender; Normal mobility; Sensibility pulp test usually } \\
\text { positive. }\end{array}$ \\
\hline 10 & Enamel-Dentin-Pulp Fracture & $\begin{array}{l}\text { A fracture involving enamel and dentin with loss of tooth structure and exposure of the } \\
\text { pulp; Normal mobility; Percussion test: not tender; Exposed pulp sensitive to stimuli. }\end{array}$ \\
\hline 11 & $\begin{array}{l}\text { Crown-Root Fracture without } \\
\text { Pulp Exposure }\end{array}$ & $\begin{array}{l}\text { A fracture involving enamel, dentin, and cementum with loss of tooth structure, but not } \\
\text { exposing the pulp; Crown fracture extending below gingival margin; Percussion test: } \\
\text { tender; Coronal fragment mobile; Sensibility pulp test usually positive for apical } \\
\text { fragment. }\end{array}$ \\
\hline 12 & $\begin{array}{l}\text { Crown-Root Fracture with Pulp } \\
\text { Exposure }\end{array}$ & $\begin{array}{l}\text { A fracture involving enamel, dentin, and cementum and exposing the pulp; Percussion } \\
\text { test: tender; Coronal fragment mobile. }\end{array}$ \\
\hline 13 & Root Fracture & $\begin{array}{l}\text { The coronal segment may be mobile and may be displaced; The tooth may be tender } \\
\text { to percussion; Bleeding from the gingival sulcus may be noted; Sensibility testing may } \\
\text { give negative results initially, indicating transient or permanent pulp damage; Transient } \\
\text { crown discoloration (red or gray) may occur. }\end{array}$ \\
\hline 14 & Alveolar Fracture & $\begin{array}{l}\text { The fracture involves the alveolar bone and may extend to adjacent bone; Segment } \\
\text { mobility and dislocation with several teeth moving together are common findings; An } \\
\text { occlusal change because of misalignment of the fractured alveolar segment is often } \\
\text { noted; Sensibility testing may or may not be positive. }\end{array}$ \\
\hline
\end{tabular}

Fig. 2. Categories of dental trauma and clinical characteristics. Adaptation from Di Angelis et al. (37) and Malmgren et al. (38)

At the end of the research, three diagnosis were formulated per patient. The first resulted from the present consultation, PD, considered the gold standard. The second was the DD based exclusively on images and the third was the DD based on the images associated to clinical data.

\subsection{Statistical Analysis}

\subsubsection{Inter-examiners agreement study}

In this study, the collected data for analysis were of the "before and after" type. Fourteen dichotomous categories $(n=14)$ of TDI, occurring in the six frontal superior teeth, were considered in this study. Each patient who constituted the sample $(n=40)$ was remotely evaluated twice by the six examiners $(r=6)$ who took part in this study. 
In order to evaluate the inter-examiners agreement, the Gwet's AC1 measure $(39,40,41)$ was used. The standard interval scale for interpreting the Gwet's AC1 agreement was as established as following: $0.8 \leq \mathrm{AC} 1 \leq 1.0$ (Very Good); $0.6 \leq \mathrm{AC} 1$ $<0.8$ (Good); $0.4 \leq \mathrm{AC} 1 \leq 0.6$ (Moderate); $0.2 \leq \mathrm{AC} 1 \leq 0.4$ (Fair) and less than 0.2 (Weak) (42).

\subsection{2 - Analyzing each trauma category and the grouped six teeth}

In clinical practice, the diagnosis for a specific case might be better formulated when, for a particular kind of trauma, the six teeth are considered altogether. In reality, when a person suffers a trauma, all six teeth may theoretically be involved. For this reason, analyzing the six teeth as a group is a realistic and more efficient way to deal with the problem of evaluating agreement among multiple examiners, although all superior anterior teeth were also individually evaluated in this study.

\subsection{3 - Conjunct analysis of inter-examiners agreement}

For the conjunct analysis, a single agreement measure among the six examiners was calculated for the 14 trauma categories, which produced 14 agreement measures. In this sense, the intention is to study the possible conjunct classification that a particular case might have.

\section{Results}

A total of 40 patients, who were attended in public and private institutions, participated in this study. Most of them (62.00\%) were male. Age varied from 3 to 39. The majority looked for an emergency service 3 hours after the accident $(52.50 \%)$. Traumas in permanent teeth were the most prevalent (62.50\%). (Table 1).

Table 1: Distribution of total samples by different characteristics.

\begin{tabular}{l|c|c}
\hline Sample Characteristics & N & $\%$ \\
\hline Gender & 25 & 62.50 \\
\hline Male & 15 & 37.50 \\
\hline Female &
\end{tabular}




\begin{tabular}{l|c|c}
\hline Age (Years) & 8 & 20.00 \\
\hline $2-4$ & 10 & 25.00 \\
\hline $5-7$ & 14 & 35.00 \\
\hline $8-10$ & 5 & 12.50 \\
\hline $11-13$ & 2 & 5.00 \\
\hline $13-21$ & 1 & 2.50 \\
\hline $22-40$ & 19 & 47.50 \\
\hline Time from trauma to first care (Hours) & 21 & 52.50 \\
\hline$\geq 2$ & \multicolumn{2}{|l}{} \\
\hline$<2$ & 33 & 82.50 \\
\hline Place where first care was provided & 7 & 17.50 \\
\hline Private Clinic & \multicolumn{2}{|l}{} \\
\hline Public Clinic & 15 & 37.50 \\
\hline Involved teeth & 25 & 62.50 \\
\hline Deciduous & \multicolumn{2}{|l}{} \\
\hline Permanent & \multicolumn{2}{|l}{} \\
\hline
\end{tabular}

Of the 40 patients, 89 teeth suffered traumatic injuries. The highest incidence was identified with Subluxation (34.83\%), followed by Enamel-Dentin Coronary Fracture (23.59\%). No cases of Intrusive Luxation, Crown-Root Fracture, Root Fracture or Alveolar Fracture were identified (Table 2).

Table 2. TDI Cases distribution

\begin{tabular}{l|c|c}
\hline \multicolumn{1}{c|}{ TDI Category } & $\mathrm{N}$ & $\%$ \\
\hline Concussion & 13 & 14.60 \\
\hline Subluxation & 31 & 34.83 \\
\hline Lateral luxation & 5 & 5.61 \\
\hline Intrusive luxation* & 0 & 0 \\
\hline Extrusive luxation & 1 & 1.12 \\
\hline Avulsion & 5 & 5.61 \\
\hline Enamel infraction & 1 & 1.12 \\
\hline Enamel fracture & 9 & 10.11 \\
\hline Enamel-dentin fracture & 21 & 23.59 \\
\hline Enamel-dentin-pulp fracture & 2 & 2.24 \\
\hline
\end{tabular}




\begin{tabular}{l|c|c}
\hline Crown-root fracture without pulp exposure* $^{*}$ & 0 & 0 \\
\hline Crown-root fracture with pulp exposure $^{*}$ & 1 & 1.12 \\
\hline Root fracture $^{*}$ & 0 & 0 \\
\hline Alveolar fracture* & 0 & 0 \\
\hline Total & 89 & 100 \\
\hline
\end{tabular}

${ }^{*}$ No cases were identified

The remote inter-examiners agreement analysis is presented in Figure 3. Being considered the Gwet's AC1 agreement measure, two profiles might be observed: One for the agreement measures when only the images were available for the examiners and another for when clinical data were associated. It is possible to establish that the agreement measures obtained from the association between images and clinical information are always superior to those based on images alone.



Fig. 3. Joint analysis - Gwet's agreement profiles calculated among the examiners when only images were available and when both images and clinical data were available for analysis. Y-axis: Gwet's AC1 Levels of agreement. Xaxis: (1) Concussion/ (2) Subluxation/ (3) Lateral Luxation/ (4) Intrusive Luxation/ (5) Extrusive Luxation/ (6) Avulsion/ (7) Enamel Infraction/ (8) Enamel Fracture/ (9) Enamel-dentin Fracture/ (10) Enamel-dentin-pulp Fracture/ (11) Crown-Root Fracture/ (12) Crown-Root Fracture with Pulp Exposure/ (13) Root Fracture/ (14) Alveolar Fracture.

Figure 4 shows the results for the conjunct analysis between the PD and the DD, expressed in comparative boxplots, for cases in which only images were available 
for the distant diagnosis. The minimum agreement value was approximately 0.65 for trauma category number 8 (Enamel Fracture). A discrepant value for category number 1 (Concussion), of approximately 0.73, was observed. Nevertheless, the correspondent boxplot unfolds a distribution highly concentrated around the agreements means. In general, for each trauma category, the obtained agreement between PD and DD was 0.83 or higher and, with exception of trauma category number 8 (Enamel Fracture), the agreement distributions were concentrated around their means, which implicates in inconsequential uncertainties.

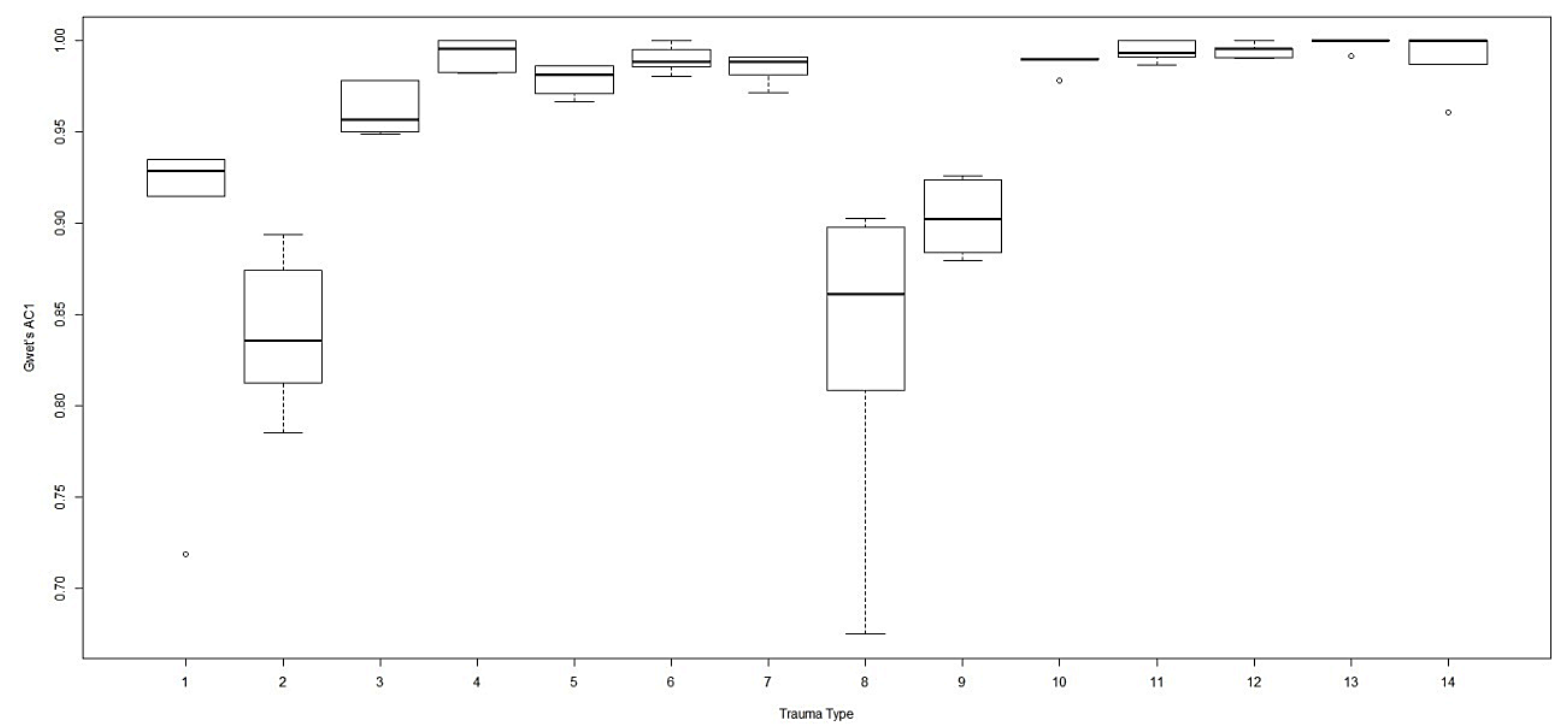

Fig. 4. Joint analysis - Comparative boxplots for the agreement measures between examiners DD and the PD for each trauma category and tooth (except left superior canine and right superior canine), calculated for the diagnostics based on images. Y-axis: Gwet's AC1 Levels of agreement (from 0.65 to 1.00). X-axis: (1) Concussion/ (2) Subluxation/ (3) Lateral Luxation/ (4) Intrusive Luxation/ (5) Extrusive Luxation/ (6) Avulsion/ (7) Enamel Infraction/ (8) Enamel Fracture/ (9) Enamel-dentin Fracture/ (10) Enamel-dentin-pulp Fracture/ (11) Crown-Root Fracture/ (12) Crown-Root Fracture with Pulp Exposure/ (13) Root Fracture/ (14) Alveolar Fracture.

Figure 5 presents the comparative boxplots for cases in which images and clinical information were available. For each trauma category, the mean agreement between PD and DD was approximately 0.93 or superior. Trauma category number 8 (Enamel Fracture) continued to have the most disperse distribution. Notwithstanding, all the agreement distributions now were even more concentrated around their highly elevated means. 


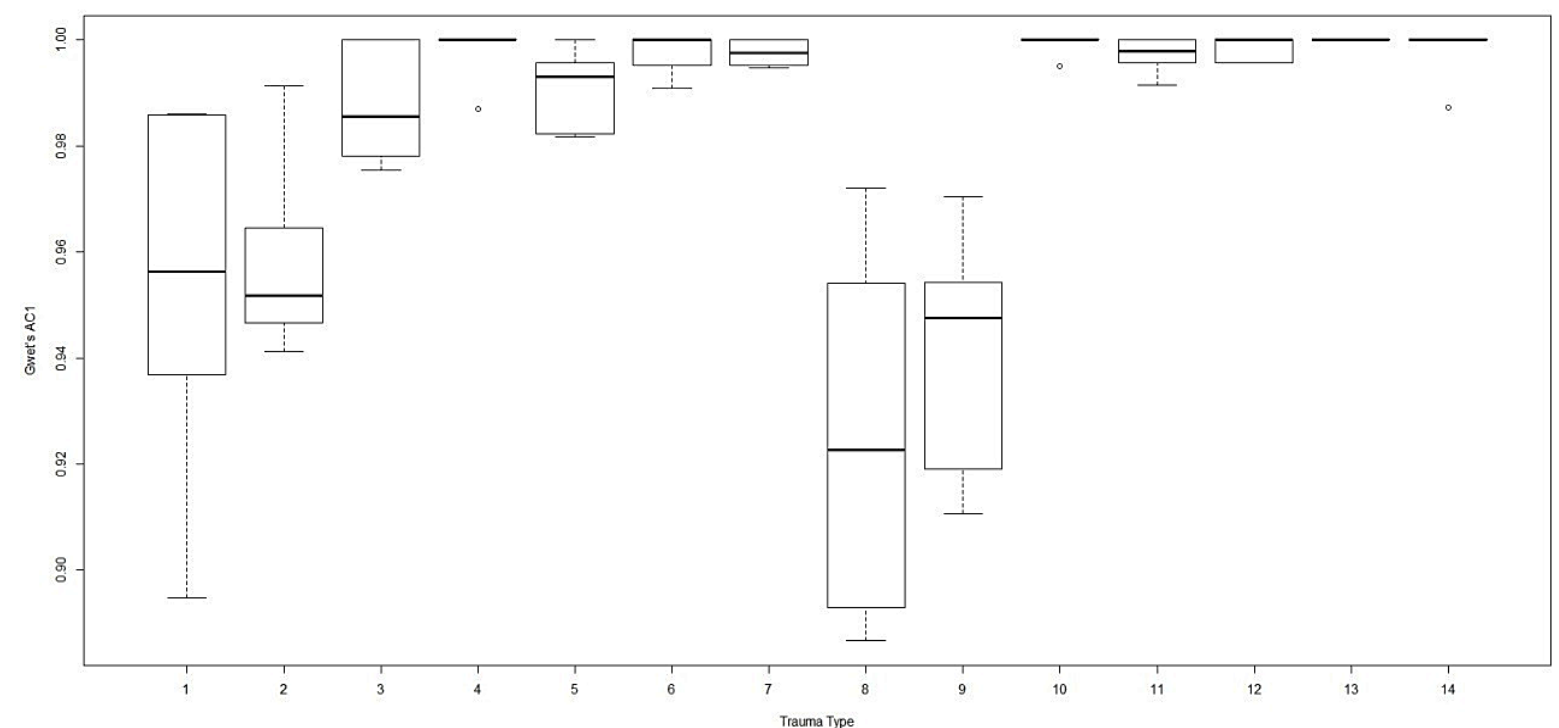

Fig. 5. Joint analysis - Comparative boxplots for the agreement measures between examiners DD and the PD for each trauma category and tooth (except left superior canine and right superior canine), calculated for the diagnostics based on images and clinical data. Y-axis: Gwet's AC1 Levels of agreement (from 0.88 to 1.00). X-axis: (1) Concussion/ (2) Subluxation/ (3) Lateral Luxation/ (4) Intrusive Luxation/ (5) Extrusive Luxation/ (6) Avulsion/ (7) Enamel Infraction/ (8) Enamel Fracture/ (9) Enamel-dentin Fracture/ (10) Enamel-dentin-pulp Fracture/ (11) CrownRoot Fracture/ (12) Crown-Root Fracture with Pulp Exposure/ (13) Root Fracture/ (14) Alveolar Fracture.

\section{Discussion}

The TD has been making feasible distant diagnoses in different dental specialties, such as in Oral Pathology, Stomatology and Pediatric Dentistry, through examinations of digital images $(22,24,25,26,27,28)$, including TDI (16). Sharing radiographic images is also possible, widening the chances of a correct diagnosis (22). Photographic cameras integrated to smartphones are considered affordable resources that may produce good quality and easily shareable images, required conditions in cases of TDI emergencies $(19,20)$.

The use of digital images for TDI diagnosis is also considered of great importance in registration, control and treatment of patients, particularly in cases of insurance compensations, legal actions and retrospective investigations (47).

Although it is proposed in literature that only two photographs (Frontal and Occlusal) are enough for registering TDI cases $(20,47)$, this study suggests a third photograph, with the teeth in occlusion, which makes possible the identification of occlusal interferences. Even though they do not alter the diagnosis in cases of lateral 
luxation in deciduous teeth, they might modify the treatment conduct. Therefore, a photograph of teeth in occlusion while capturing images for the distant diagnosis of TDI is justifiable.

For this study, the Gwet's AC1 measure (36) was used, with the objective of studying agreement among diagnoses formulated by six remote professional examiners, as well as comparisons between the PD and DD.

It might be observed in this study that, when the agreement among remote examiners is assessed, lighter traumas such as Concussion and Enamel Fracture presented a lower agreement. This condition is possibly justified by the fact that alterations associated to these traumas are discretely showed and observed in images. In cases of more severe traumas, agreement levels tend to be higher.

The agreement level of 0.83 or superior, considered very good, was found in the PD and DD, when just images were used, with an exception in the trauma category number 8 (Enamel Fracture). The agreement distributions were concentrated around the means, what implicates in little dubiety concerning the diagnosis formulated for each one of the patients in the study.

The agreement levels were increased to 0.93 or superior when clinical data were associate to images. Trauma category number 8 (Enamel Fracture) remained having the most disperse distribution. Apart from the Enamel Fracture, the uncertainty towards the DD is practically null, what means that when clinical data were made available, the remote examiners could formulate more precise diagnosis, comparable to the PD.

In this study, the highest TDI distribution was observed within the 8-10 age group, which is in accordance with a study performed on an American pediatric emergency service with 264 patients (43). An almost absolute predominance (97.50\%) of children and adolescents (3-16 years old) as constituents of sample was observed. That might be justified by the fact that the private clinic, where most of the patients were examined (82.50\%), is specialized in the attention for children and adolescents, and offers a 24-hour emergency service. This tendency was also observed in the public clinic, even though its service is not focused on any specific age group. 
The images used in this study were captured with a digital photographic camera integrated to a cell phone device. The option for this equipment was made given the ease and convenience in capturing and sharing images it offers in cases of TDI (20). By choosing a cell phone camera, and not using retractors or intraoral mirrors, it was intended to simulate conditions in which laypersons might take pictures of the TDI cases and remotely share them with a professional, so that they could be oriented on first aid procedures and correlated information. A study performed with 97 pediatric dentists in 2014, in Distrito Federal, Brazil, concluded that $76.29 \%$ of these professionals had already been requested remote help by patients or other professionals in cases of TDI (Data not published).

The clinic-radiographic diagnosis is always recommended in TDI, mostly in cases of root and alveolar fractures in which an exclusively clinic diagnosis has limitations. Even so, a clinical evaluation is primordial, for it also determines the most adequate therapeutic technique and complementary radiographic examinations towards the TDI (44). Unfortunately, ideal conditions to the clinic-radiographic diagnosis in TDI are not always possible. In Brazil, most of the public or private dental clinics are not equipped for radiographic diagnosis. Lira-Júnior in his study points that only $47.9 \%$ of Brazilian cities have at least one dental X-ray device, and this number reduces to $35.6 \%$ when only the public service is considered (45).

Another limitation to the radiographic diagnosis is the behavioral condition of non-cooperative patients, especially when dealing with children (38). Limitations to the radiographic diagnosis were also found in studies with high scientific evidence levels, which used exclusively clinical evaluations for the diagnosis of TDI (46).

It must be considered that the absence of TDI categories in which radiographic examinations are considered necessary for the diagnosis, such as Radicular and Alveolar Fractures (44), probably increased the levels of inter-examiners agreement in this current study. The possibility of sharing radiographic images, which might aid the distant diagnosis in these traumas, must also be considered (22).

\section{Conclusion}


The DD is comparable to the PD in most cases of TDI when formulated by calibrated professionals. The levels of inter-examiners agreement are higher when clinical data are associated to images. The use of images captured with cell phones is an effective tool and assists the distant diagnosis in cases of TDI.

Conflict of interest

None of the authors have conflicts of interest to report.

\section{References}

1. Glendor $U$, Jonsson D, Halling A, Lindqvist $K$. Direct and indirect costs of dental trauma in Sweden: a 2-year prospective study of children and adolescents. Community dentistry and oral epidemiology 2001;29:150-160.

2. Wong FSL, Kolokotsa K. The cost of treating children and adolescents with injuries to their permanent incisors at a dental hospital in the United Kingdom. Dent Traumatol 2004;20:327-333.

3. Guedes AO, Alencar AHG, Lopes LG, Pécora JD, Estrela CA. Retrospective study of traumatic dental injuries in a Brazilian dental urgency service. Braz Dent $\mathrm{J}$ 2010;21:153-157.

4. Glendor Ulf. Epidemiology of traumatic dental injuries-a 12 year review of the literature. Dent traumatol 2008;24:603-611.

5. Levin L, Zadik Y. Education on and prevention of dental trauma: it's time to act! Dent Traumatol 2012;28:49-54.

6. Kramer PF, Feldens EG, Bruch CM, Ferreira SH, Feldens CA. Clarifying the effect of behavioral and clinical factors on traumatic dental injuries in childhood: a hierarchical approach. Dent Traumatol 2015;31:177-183.

7. Borzabadi-Farahani, A, Borzabadi-Farahani A, Eslamipour F. An investigation into the association between facial profile and maxillary incisor trauma, a clinical nonradiographic study. Dent Traumatol 2010;26:403-408.

8. Petti S. Over two hundred million injuries to anterior teeth attributable to large overjet: a meta-analysis. Dent Traumatol 2015;31:1-8.

9. Basha S, Noor Mohammad R, Shivalinga Swamy H. Incidence of dental trauma among obese adolescents - a 3-year-prospective study. Dental Traumatol 2015;31:125-129. 
10. Bhat, N, Agrawal A, Nagrajappa R, Roy SS, Singh K, Chaudhary H, Asawa K. Teeth fracture among visually impaired and sighted children of 12 and 15 years age groups of Udaipur city, India - a comparative study. Dent Traumatol 2011;27:389-392. 11. Bendo CB, Paiva SM, Torres CS, Oliveira AC, Goursand D, Pordeus IA, Vale MP. Association between treated/untreated traumatic dental injuries and impact on quality of life of Brazilian schoolchildren. Health Qual Life Outcomes 2010;8:114.

12. Kramer PF, Feldens CA, Ferreira SH, Bervian J, Rodrigues PH, Peres MA . Exploring the impact of oral diseases and disorders on quality of life of preschool children Community Dent Oral Epidemiol 2013;41:327-335.

13. Needleman HL. The art and science of managing traumatic injuries to primary teeth. Dent Traumatol 2011;27:295-299.

14. Alnaggar D, Andersson L. Emergency management of traumatic dental injuries in 42 countries. Dent Traumatol 2015;31:89-96.

15. Zhang Y, Zhu Y, Su W, Zhou Z, Jin Y, Wang X. A retrospective study of pediatric traumatic dental injuries in Xi'an, China. Dent Traumatol 2014;30:211-215.

16. Amável R, Cruz-Correia R, Frias-Bulhosa J. Remote diagnosis of children dental problems based on non-invasive phohtographs - A valid proceeding? Stud Health Technol Inform 2009;150:458-462.

17. Lieinert N, Zitzmann NU, Filippi A, Weiger R, Krastl G. Teledental consultations related to trauma in a Swiss telemedical center: a retrospective survey. Dent Traumatol 2010;26:223-227.

18. Levin L, Zadik Y. Education on and prevention of dental trauma: it's time to act! Dent Traumatol 2012;28:49-54.

19. Park W, Kim DK, Kim JC, Kim KD, Yoo SK. A portable dental image viewer using a mobile network to provide a tele-dental service. J Telemed Telecare 2009;15:145149.

20. Park W, Lee HN, Jeong JS, Kwon JH, Lee GH, Kim KD. Optimal protocol for teleconsultation with a cellular phone for dentoalveolar trauma: an in-vitro study. Imaging science in dentistry 2012;42:71-75.

21. Khan SA, Omar H. Teledentistry in Practice: Literature Review. Telemedicine and e-Health 2013;19:7.

22. Bradley M, Black P, Noble S, Thompson R, Lamey PJ. Application of teledentistry in oral medicine in a community dental service, N. Ireland. British dental jornal 2010;209:399-404. 
23. Rocca MA, Kudryk VL, Pajak JC, Morris T. The evolution of a teledentistry system within the Department of Defense. Proc AMIA Symp 1999;921-924.

24. Kopycka-Kedzierawski DT, Billings RJ, McConnochie KM. Dental screening of preschool children using teledentistry: a feasibility study. Pediatric dentistry 2007;29:209-213.

25. Kopycka-Kedzierawski DT, Bell CH, Billings RJ. Prevalence of dental caries in Early Head Start children as diagnosed using teledentistry. Pediatric dentistry 2008;30:329-333.

26. Morosini IAC, Oliveira DC, Ferreira FM, Fraiz FC, Torres-Pereira CC. Performace of Distant Diagnosis of Dental Caries by Teledentistry in Juvenile Offenders. Telemedicine and e-Health 2014;20:584-589.

27. Torres-Pereira C, Possebon RS, Simões A, Bortoluzzi MC, Leão JC, Giovanini AF, Piazetta CM. Email for distance diagnosis of oral diseases: a preliminary study of teledentistry. Journal of telemedicine and telecare 2008;14:435-438.

28. Torres-Pereira CC, Morosini IAC, Possebon RS, Giovanini AF, Bortoluzzi MC, Leão JC, Piazzetta CM. Teledentistry: Distant Diagnosis of Oral Disease Using EMails. Telemedicine and e-Health 2013;19:117-121.

29. Bhambal A, Saxena S, Balsaraf SV. Teledentistry: potentials unexplored. J Int Oral Health 2010;2:1-6.

30. Mariño R, Ghanim A. Teledentistry: a systematic review of the literature. Journal of Telemedicine and Telecare 2013;1-5.

31. Mariño R, Manton D, Marwaha P, Hallett K, Clarke K, Hopcraft M, McCullough M, Borda A. The Implementation of Teledentistry fot Pediatric Patients. Global Health 2014, The Third International Conference on Global Health Challenges. p.14-19.

32. Feldens CA, Kramer PF, Feldens EG. Exploring the profile of articles on traumatic dental injuries in pediatric dental journals. Dent Traumatol 2013;29:172-177.

33. Castro JCM, Poi WR, Manfrin TM, Zina LG. Analysis of the crown fractures and crown-root fractures due to dental trauma assisted by the Integrated Clinic from 1992 to 2002. Dent traumatol 2005;21:121-126.

34. PowerBinary em R Package kappaSize. The Comprehensive R Archive Network. Available at: http://cran.r-project.org/. 20150428.

35. Donner A, Rotondi MA. Tamanho Requisitos exemplo para Interval Estimativa da Kappa para interavaliadores Estudos de concordância com um resultado binário e múltiplos avaliadores. Revista Internacional de Bioestatística 2010;06:31. 
36. Andreasen JO, Andreasen FM, Andersson L. Textbook and Color Atlas of traumatic injuries to the teeth, 4th edn. Oxford: Blackwell-Munksgaard; 2007.

37. DiAngelis AJ, Andreasen JO, Ebeleseder KA, Kenny DJ, Trope M, Sigurdsson A, Andersson L, Bourguignon C, Flores MT, Hicks ML, Lenzi AR, Malmgren B, Moule AJ, Pohl $Y$ and Tsukiboshi M. International Association of Dental Traumatology guidelines for the management of traumatic dental injuries: 1. Fractures and luxations of permanent teeth. Dent Traumatol 2012;28:2-12.

38. Malmgren B, Andreasen JO, Flores MT, Robertson A, DiAngelis AJ, Andersson L, Cavalleri G, Cohenca N, Day P, Hicks ML, Malmgren O, Moule AJ, Onetto J, Tsukiboshi M. International Association of Dental Traumatology guidelines for the management of traumatic dental injuries: 3. Injuries in the primary dentition. Dent Traumatol 2012;28:174-182.

39. Gwet, KL. Computando confiabilidade entre avaliadores e sua variância na presença de alta concordância. British Journal of Psychology Matemática e Estatística 2008;61:29-48.

40. Wongpakaran, N., Wongpakaran, T., Casamento, D. e Gwet, KL. A comparação de Kappa e Gwet de Cohen AC1 quando o cálculo dos coeficientes de confiabilidade entre avaliadores: um estudo realizado com amostras de transtorno de personalidade Medical Research Metodologia 2013;13:61.

41. Gwet, KL. Inter-Rater Reability With R. Inter-Rate Reliability Publications. Available at: http://www.agreestat.com/r_functions.html. 20150428.

42. Gwet, KL. Gwet's Inter-Rater Reliability Blog. Available at: http://inter-raterreliability.blogspot.com.br/. 20150621.

43. Ritwik P, Massey C, Hagan J. Epidemiology and outcomes of dental trauma cases from an urban pediatric emergency department. Dent Traumatol 2015;31:97-102.

44. Kullman L, Al Sane M. Guidelines for dental radiography immediately after a dentoalveolar trauma, a systematic literature review. Dent traumatol 2012;28(3):193-199.

45. Lira-Junior R, Wanderley Cavalcanti Y, De Fátima Dantas de Almeida L, Oliveira de Sales MA. Panorama da Radiologia Odontológica no Brasil: disponibilidade de aparelhos e produção ambulatorial de radiografias. Rev Cubana Estomatol 2012;49:223-231.

46. Aldrigui JM, Jabbar NS, Bonecker M, Braga MM, Wanderley MT. Trends and associated factors in prevalence of dental trauma in Latin America and Caribbean: a 
systematic review and meta-analysis. Community dentistry and oral epidemiology 2014;42:30-42.

47. Andreasen FM.; Andreasen JO. Diagnosis of luxation injuries: the importance of standardized clinical, radiographic and photographic techniques in clinical investigations. Dent Traumatol 1985;1:160-169. 


\section{DISCUSSÃO}

\subsection{DA METODOLOGIA}

Os dados desta pesquisa foram coletados por um único pesquisador durante o período de um ano. No artigo 1, a amostra foi representativa da população de odontopediatras do Distrito Federal, com $n=97$ (37,16\%), pois foram convidados todos os odontopediatras inscritos no Conselho Regional de Odontologia-Distrito Federal com e-mail cadastrado $(n=261 ; 92,55 \%)$. No artigo 2 , a amostra foi selecionada por conveniência, de maneira não aleatória, em duas clínicas representativas do atendimento ao TD no Distrito Federal (Pública e Privada), em função da dificuldade para reunir um número mínimo de pacientes necessários para compor a amostra. O questionário, formulários e termos de consentimento utilizados nesta pesquisa, bem como a autorização do comitê de ética, estão listados no apêndices $A, B, C, D, E, F$, e G e no Anexo 1.

Em relação à análise estatística realizada no artigo 1, um estudo preliminar foi realizado buscando-se associações entre as variáveis em estudo, onde selecionou-se dentre as quatrocentas e trinta cinco possibilidades de cruzamentos entre os trinta itens do questionário, cinquenta cruzamentos, entretanto apenas três itens obtiveram significância a 5\%. (Itens $12 \times 14,19 \times 17$ e $29 \times 30$ ). Nessa análise preliminar utilizouse teste Qui-quadrado e simulação de Monte Carlo com valor de $P$ menor que 0,05 $(45,46)$. Entretanto diante do pequeno número de associações encontradas decidiuse substituir a análise, realizando-se a fatoração dos itens do questionário (Apêndice B) e a análise de correlação de Person entre esses fatores $(47,48)$.

No artigo 2, a fim de avaliar a concordância interexaminadores, inicialmente considerou-se o uso do coeficiente Kappa de Cohen (49). Apesar de sua popularidade como a medida sumária mais utilizada para avaliar a confiabilidade interexaminadores, vários autores $(50,51,52,53,54,55,56,57,58)$ apontam deficiências de tal abordagem para avaliar o grau de concordância entre dois ou mais avaliadores. As deficiências na análise de Kappa, de acordo com Uebersax (59): (I) Kappa não é realmente uma medida corrigida pela chance de concordância. (II) Kappa não faz distinções entre vários tipos e fontes de desacordo. (III) Kappa é influenciada 
pela prevalência de traço. (IV) Kappa pode ser baixa, mesmo quando há altos níveis de concordância.

Gwet (57) propôs uma outra abordagem para avaliação de concordância que revê e resolve várias dessas deficiências. Wongpakaran et al. (58) mostraram que a medida de concordância AC1 Gwet não muda dramaticamente com a prevalência em comparação com Kappa de Cohen, mesmo para os casos em que a prevalência seja extremamente pequena. Gwet disponibilizou várias rotinas para o cálculo de seus métodos propostos $(60,61)$ que foram utilizadas neste trabalho.

Não se realizou uma análise confirmatória como, por exemplo, teste t-Student pareados, porque a amostra obtida para as análises não foi de forma aleatória. No entanto, apesar das limitações por testes conclusivos neste estudo, os resultados das análises evidenciaram uma elevada concordância entre os diagnósticos realizados presencialmente e a distância, sugerindo que a TO pode ser uma ferramenta eficaz no atendimento e manejo dos TD.

\subsection{DOS RESULTADOS}

Diariamente inúmeros grupos são criados nas redes sociais, incontáveis emails são enviados e recebidos, milhares de vídeos, fotos, mensagens de voz e textos são compartilhados por meios eletrônicos, incluindo os que buscam por ajuda ou auxiliam profissionais de saúde nas suas práticas profissionais.

Observa-se atualmente que uma das grandes limitações no atendimento convencional dos TD é a disponibilidade e preparo técnico-científico dos dentistas (8, 9, 10, 11). Este trabalho vem ao encontro das propostas de Feldens et al. (15) que sugerem a necessidade de estudos sobre novas tecnologias e serviços na área da traumatologia dentária; e de Mariño e Ghanim (16) que reforçam a necessidade de pesquisas em TO em outras regiões do mundo, além dos EUA e Europa.

O primeiro estudo apresentado evidenciou que o uso de ferramentas da TO já é uma realidade na prática clínica diária dos odontopediatras do Distrito Federal. Ainda que apresente limitações, os benefícios da TO são práticos e acessíveis aos profissionais. Evidencia-se dessa forma, em função de sua expressiva utilização, a 
necessidade do estabelecimento de mecanismos regulatórios por parte dos Conselhos de Odontologia, não com a intenção de limitar o seu uso, mas de reconhecer, orientar, legitimar e até mesmo estimular e ampliar o uso da TO no atendimento ao TD e em outras áreas da odontologia, observada a multidisciplinaridade envolvida no atendimento ao TD. A normatização da utilização dos recursos tecnológicos atualmente disponíveis na prática odontológica beneficiará a TO, aumentado a segurança de dentistas e pacientes.

No segundo estudo, demostrou-se que o uso de uma ferramenta acessível para a TO, como fotografias realizadas por telefone celular, pode viabilizar o diagnóstico a distância de casos de TD em dentes ântero-superiores. Evidenciou-se que o diagnóstico realizado a distância com imagens produzidas por câmeras fotográficas integradas a aparelhos celulares é equivalente ao diagnóstico realizado presencialmente, em razão dos elevados níveis de concordância interexaminadores encontrados. Considerando a facilidade para a realização e envio das fotografias para serem analisadas a distância, especula-se que pessoas leigas, desde que bem orientadas, podem realizar fotografias adequadas e enviá-las aos profissionais para serem analisadas a distância nos casos de TD, favorecendo o rápido diagnóstico e em última análise o prognóstico em relação ao tratamento dessas lesões.

Futuras pesquisas são necessárias para avaliar a acurácia dos diagnósticos a distância a fim de validar sua aplicação no atendimento dos TD.. 


\section{CONCLUSÕES}

- A maioria dos odontopediatras do Distrito Federal, Brasil, já utilizaram ferramentas da TO no atendimento aos casos de TD e tiveram percepções e atitudes positivas em relação a elas.

- Fotografias digitais obtidas por telefone celular são ferramentas eficazes no auxílio ao diagnóstico a distância em casos de TD.

- O diagnóstico a distância utilizando-se imagens é equivalente ao diagnóstico clínico presencial na maioria dos casos de TD. 


\section{REFERÊNCIAS}

01. Chopra A, Lakhanpal M, Rao NC, Gupta N, Vashisth S. Traumatic Dental Injuries Among Twelve to Fifteen Year-Old School Children in Panchkula. Arch Trauma Res. 2014;3(1):e18127.

02. Andersson L. Epidemiology of traumatic dental injuries. Journal of endodontics. 2013;39(3):S2-5.

03. Petersen PE. The World Oral Health Report 2003: continuous improvement of oral health in the 21st century-the approach of the WHO Global Oral Health Programme. Community Dentistry and oral epidemiology. 2003;31(s1):3-24.

04. Glendor U, Andersson L. Public health aspects of oral diseases and disorders: dental trauma. In: Pine G, Harris R, editors. Community Oral Health. London: Quintessence Publishing. 2007. p. 203-14.

05. Glendor U. Epidemiology of traumatic dental injuries-a 12 year review of the literature. Dental Traumatology. 2008;24(6):603-11.

06. Bendo CB, Paiva SM, Abreu MH, Figueiredo LD, Vale MP. Impact of traumatic dental injuries among adolescents on family's quality of life: a population-based study. International Journal of Paediatric Dentistry. 2014;24:387-96.

07. Bendo CB, Paiva SM, Torres CS, Oliveira AC, Goursand D, Pordeus IA, Vale MP. Association between treated/untreated traumatic dental injuries and impact on quality of life of Brazilian schoolchildren. Health Qual Life Outcomes. 2010;8:114.

08. Lieinert N, Zitzmann NU, Filippi A, Weiger R, Krastl G. Teledental consultations related to trauma in a Swiss telemedical center: a retrospective survey. Dental Traumatology. 2010;26:223-7.

9. Glendor U, Jonsson D, Halling A, Lindqvist K. Direct and indirect costs of dental trauma in Sweden: a 2-year prospective study of children and adolescents. Community Dentistry and Oral Epidemiology. 2001;29(2):150-60.

10. Yeng T, Parashos P. Dentists' management of dental injuries and dental trauma in Australia: a review. Dental Traumatology. 2008;24:268-71.

11. De França RI, Traebert J, De Lacerda JT. Brazilian dentists' knowledge regarding immediate treatment of traumatic dental injuries. Dental Traumatology. 2007;23:28790. 
12. Borum MK, Andreasen JO. Therapeutic and economic implications of traumatic dental injuries in Denmark: an estimate based on 7549 patients treated at a major trauma centre. International Journal of Paediatric Dentistry. 2001;11(4):249-58.

13. Park W, Lee HN, Jeong JS, Kwon JH, Lee GH, Kim KD. Optimal protocol for teleconsultation with a cellular phone for dentoalveolar trauma: an in-vitro study. Imaging Science in Dentistry. 2012;42(2):71-5.

14. Daniel SJ, Wu L, Kumar S. Teledentistry: A Systematic Review of Clinical Outcomes, Utilization and Costs. American Dental Hygienists Association. 2013;87(6): 345-52.

15. Feldens CA, Kramer PF, Feldens EG. Exploring the profile of articles on traumatic dental injuries in pediatric dental journals. Dental Traumatology. 2013;29(3):172-7.

16. Mariño R, Ghanim A. Teledentistry: a systematic review of the literature. Journal of Telemedicine and Telecare. 2013;19(4):179-83.

17. Guedes AO, Alencar AHG, Lopes LG, PécoraJD, Estrela CA. Retrospective study of traumatic dental injuries in a Brazilian dental urgency service. Braz Dent J. 2010;21:153-7.

18. Amorim LD, Da Costa LR, Estrela C. Retrospective study of traumatic dental injuries in primary teeth in a Brazilian specialized pediatric practice. Dental Traumatology. 2011;27:368-73.

19. Glendor U, Halling A, Andersson L, Eilert-Petersson E. Incidence of traumatic tooth injuries in children and adolescents in the county of Västmanland, Sweden. Swed Dent J. 1996;20:15-28.

20. Raoof M, Zaherara F, Shokouhinejad N, Mohammadalizadeh S. Elementary school staff knowledge and attitude with regard to first-aid management of dental trauma in Iran: a basic premise for developing future intervention. Dental Traumatology. 2012;28(6):441-7.

22. Shuch HS, Goettems ML, Correa MB, Torriani DD, Demarco FF. Prevalence and treatment demand after traumatic dental injury in South Brazilian schoolchildren. Dental Traumatology. 2013;29(4):297-302.

22. Ministério da Saúde. SB Brasil 2010 - Pesquisa Nacional de Saúde Bucal. Resultados Principais. Brasília: Departamento de Atenção Básica, Secretaria de Atenção Básica, Ministério da Saúde; 2011 [citado em 18 jun. 2015] p-24. Disponível 
em:

http://dab.saude.gov.br/CNSB/sbbrasil/arquivos/projeto_sb2010_relatorio_final.pdf. 23. Ramos-Jorge J, Paiva SM, Tataounoff J, Pordeus IA, Masques LS, Ramos-Jorge ML. Impact of treated/untreated traumatic dental injuries on quality of life among Brazilian schoolchildren. Dental Traumatology. 2014;30(1):27-31.

24. Petersen PE. Priorities for research for oral health in the 21 st Century - the approach of the WHO Global Oral Health Programme. Community Dental Health. 2005;22:71-4.

25. Wong FSL, Kolokotsa K. The cost of treating children and adolescents with injuries to their permanent incisors at a dental hospital in the United Kingdom. Dental Traumatology. 2004;20:327-33.

26. Sheiham A, Watt RG. The Common Risk Factor Approach: a rational basis for promoting oral health. Community Dent Oral Epidemiol, 2000;28:399-406.

27. Levin L, Zadik Y. Education on and prevention of dental trauma: it's time to act! Dental Traumatology. 2012;28(1):49-54.

28. Jackson NG, Waterhouse PJ, Maguire A. Management of dental trauma in primary care: a postal survey of general dental practitioners. Br Dent J. 2005;198:293-7.

29. Khan SA, Omar H. Teledentistry in Practice: Literature Review. Telemedicine and e-Health. 2013;19(7):565-7.

30. Bradley M, Black P, Noble S, Thompson R, Lamey PJ. Application of teledentistry in oral medicine in a Community Dental Service, N. Ireland. British Dental Journal. 2010;209:399-404.

31. Rocca MA, Kudryk VL, Pajak JC, Morris T. The evolution of a teledentistry system within the Department of Defense. In Proceedings of the AMIA Symposium. American Medical Informatics Association [Internet]. 1999 [citado em 20 jun. 2013];p.921-24. Disponível em: http://www.ncbi.nlm.nih.gov/pmc/articles/PMC2232632/?page=1.

32. Rollert MK, Strauss RA, Abubaker AO, Hampton C. Telemedicine consultations in oral and maxillofacial surgery. Journal of Oral and Maxillofacial Surgery. 1999;57(2):136-8.

33. Leão JC, Porter SR. Telediagnosis of oral disease. Braz Dent J. 1999;10(1):47-53. 34. Kopycka-Kedzierawski DT, Bell CH, Billings RJ. Prevalence of dental caries in Early Head Start children as diagnosed using teledentistry. Pediatric Dentistry. 2008;30(4):329-33. 
35. Morosini IAC, Oliveira DC, Ferreira FM, Fraiz FC, Torres-Pereira CC. Performace of Distant Diagnosis of Dental Caries by Teledentistry in Juvenile Offenders. Telemedicine and e-Health. 2014;20(6):584-9.

36. Amável R, Cruz-Correia R, Frias-Bulhosa J. Remote diagnosis of children dental problems based on non-invasive phothographs - A valid proceeding? Stud Health Technol Inform. 2009;150:458-62.

38. Younai FS, Messadi DV. E-mail-based oral medicine consultation. Journal of the California Dental Association. 2000;28(2):144-51.

39. Bhambal A, Saxena S, Balsaraf SV. Teledentistry: potentials unexplored! J Int Oral Health. 2010;2:1-6.

40. Brasil. Telessaúde Brasil Redes. Telessaúde Brasil Redes na Atenção Básica. Brasília, DF. [citado em 18 jun. 2015]. Disponível em: http://dab.saude.gov.br/portaldab/ape_telessaude.php.

41. Brasil. Telessaúde Brasil Redes. SIEDIS e-Diagnóstico. Ferramenta exclusiva para médicos, dentistas e enfermeiros do SUS no Estado do Rio de Janeiro. Rio de janeiro: UERJ [citado em 18 jun. 2015]. Disponível em: http://www.telessaude.uerj.br/telediagnostico/.

42. Andersson L, Andreasen JO, Day P, Heitheersay G, Trope M, DiAngelis AJ, Kenny DJ, Sigurdsson A, Bourguignon C, Flores MT, Hicks ML, Lenzi AR, Malmgren B, Moule AJ, Tsukiboshi M. International Association of Dental Traumatology guidelines for the management of traumatic dental injuries: 2. Avulsion of permanent teeth. Dental Traumatology. 2012;28:88-96.

43. Glendor Ulf. Dental trauma Ulf Glendor LTD. [Aplicativo para celulares e tablets]. [18 julho 2015]. Disponível em: www.iadt-dentaltrauma.org.

44. Park W, Kim DK, Kim JC, Kim KD, Yoo SK. A portable dental image viewer using a mobile network to provide a tele-dental service. J Telemed Telecare. 2009;15:1459.

45. Sturges HA. The Choise of a Class Interval. American Statistical Association [Internet]. 1926 [citado em 18 jun. 2015]; 21(153). Disponível em: http://www.jstor.org/stable/2965501.

46. Bruni $A L$, Famá R, Siqueira JO. Análise de risco na avaliação de projetos de investimento: uma aplicação do Método de Monte Carlo [Internet]. 1998. [citado em 18 jun. 2015];

em: http://www.infinitaweb.com.br/albruni/academicos/bruni9802.pdf. 
47. Pasquali L. Instrumentos psicológicos: Manual prático de elaboração. Brasília: LabPAM; IBAP; 1999.

48. Pasquali L. Psicometria: Teoria dos testes na psicologia e na educação. Petrópolis: Vozes; 2003.

49. Cohen J. A coefficient of agreement for nominal scales. Educational and psychological measurement. 1960;20(1):37-46.

50. Uebersax JS. Measuring diagnostic reliability.[Reply to Spitznagel and Helzer letter]. Arch Gen Psychiatry. 1987a;44:193-4.

51. Uebersax JS. Diversity of decision-making models and the measurement of interrater agreement. Psychological Bulletin. 1987b;101(1):140-6.

52. Thompson WD, Walter SD. A reappraisal of the kappa coefficient. Journal of clinical epidemiology. 1988a;41(10):949-58.

53. Thompson WD, Walter SD. Response Kappa and the concept of independent errors. Journal of Clinical Epidemiology. 1988b;41(10):969-70.

54. Feinstein AR, Cicchetti DV. High agreement but low kappa: I. The problems of two paradoxes. Journal of clinical epidemiology. 1990;43(6):543-9.

55. Gwet KL. Handbook of confiabilidade inter-examinadores. STATAXIS Publishing Company, 2002a.

56. Gwet KL. Kappa Statistic is not Satisfactory for Assessing the Extent of Agreement Between Raters. Statistical Methods for inter-rater Assessment. 2002;1(6):1-6.

57. Gwet KL. Computing inter-rater reliability and its variance in the presence of high agreement. British Journal of Psychology Mathematical and Statistical Psychology. 2008;61:29-48.

58. Wongpakaran N, Wongpakaran T, Wedding D, Gwet KL. A comparison of Cohen's Kappa and Gwet's AC1 when calculating inter-rater reliability coefficients: a study conducted with personality disorder samples.BMC medical research methodology. 2013;13(1):61.

59. Uebersax JS. Kappa coefficients: A critical appraisal. Statistical methods for rater agreement. 2002.

60. Gwet KL. Inter-Rate Reliability Publications - Inter-Rater Reability With R [Internet]. [citado em 2015 Jun. 18]. Disponível em: http://www.agreestat.com/r_functions.html. 61. Gwet KL. K. Gwet's Inter-Rater Reliability Blog [Internet]. Kilem L. Gwet. 2014 Dec. [citado em 2015 Jun. 18]. Disponível em: http://inter-rater-reliability.blogspot.com.br. 
1. Qual a sua idade:

2. Sexo:

Feminino

Masculino

3. Tempo de especialização:

4. Você possui computador ou celular com conexão à internet?

$\operatorname{Sim}$

Não

5. Em caso de resposta positiva a questão anterior, qual o tempo diário conectado(a) à internet:

Considerando a definição de Teleodontologia a seguir, respondas as questões de 6 a 29.

"A Teleodontologia pode ser definida como a prestação de serviços odontológicos à distância, orientações ou tratamento por meio da tecnologia da informação, substituindo o contato pessoal direto com o paciente envolvido. As aplicações da Teleodontologia podem envolvem registros eletrônicos de pacientes, diagnósticos, sistemas de apoio à decisão clínica e educação dos pacientes". (KHAN, S.A.; OMAR, H., 2013).

6. Você possui conhecimento para envio e recebimento eletrônico de imagens, mensagens de texto e voz, recursos fundamentais para a prática da teleodontologia?

$$
\begin{aligned}
& \text { Sim } \\
& \text { Não }
\end{aligned}
$$



do Distrito Federal no atendimento aos Traumatismos Dentários

7. Você já recebeu algum telefonema, email, mensagens de texto, mensagens multimídia, videochamadas ou mensagens postadas em redes sociais solicitando orientações odontológicas?

$$
\text { Sim }
$$

8. Você já recebeu algum telefonema, email, mensagens de texto, mensagens multimídia, videochamadas ou mensagens postadas em redes sociais solicitando orientações sobre traumatismos dentários (Concussões, subluxações, luxações, avulsões, fraturas dentárias, fraturas alveolares)?

$$
\begin{aligned}
& \text { Sim } \\
& \text { Não }
\end{aligned}
$$

9. O uso de imagens (fotos ou vídeo) associadas a textos descritivos ou mensagens de voz aumenta a compreensão das informações compartilhadas na teleodontologia.
Concordo Plenamente
Concordo
Neutro
Discordo
Discordo Plenamente

10. O investimento financeiro nos recursos tecnológicos necessários à prática da teleodontologia inviabiliza a sua utilização rotineira.
- Concordo Plenamente
Concordo
Neutro
Discordo
Discordo Plenamente 
11. É possível orientar pessoas leigas à distância, para os primeiros socorros nos casos de traumatismos dentários.
- Concordo plenamente
Concordo
Neutro
Discordo
Discordo Plenamente

12. Orientar pessoas leigas à distância, para os primeiros socorros nos casos de traumatismos dentários não implica em infração ao código de ética odontológica.
Concordo plenamente
Concordo
Neutro
Discordo
Discordo Plenamente

13. É possível compartilhar com outros profissionais imagens e informações com o objetivo de melhorar o diagnóstico, tratamento e prognóstico em casos de traumatismos dentários.
Concordo plenamente
Concordo
Neutro
Discordo
Discordo plenamente 
14. Compartilhar com outros profissionais imagens e informações com o objetivo de melhorar o diagnóstico, tratamento e prognóstico em casos de traumatismos dentários não implica em infração ao código de ética odontológica.

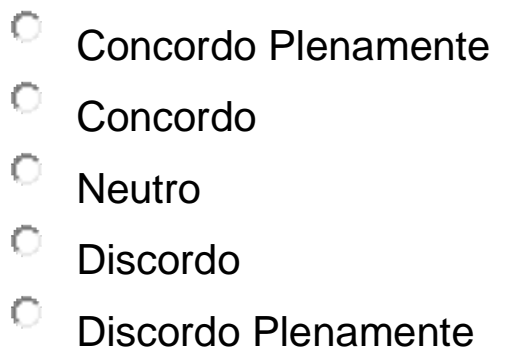

15. Quando recebemos mensagens de textos, imagens e vídeos de pacientes para fins de consulta, devemos considerar estes dados sigilosos.
- Concordo plenamente
Concordo
Neutro
Discordo
Discordo Plenamente

16. Profissionais menos experientes, orientados à distância por profissionais mais experientes podem executar condutas mais adequadas frente aos casos de traumatismos dentários.
Concordo plenamente
Concordo
C Neutro
Discordo
Discordo Plenamente 
17. Nos casos de traumatismos dentários a avaliação clínica presencial realizada pelo dentista é fundamental na elaboração de um correto diagnóstico.

Concordo plenamente

Concordo

Neutro

Discordo

Discordo Plenamente

18. Nos casos de traumatismos dentários, o tempo decorrido até o primeiro atendimento é muito importante.

- Concordo plenamente

Concordo

Neutro

Discordo

Discordo Plenamente

19. Nos casos de traumatismos dentários os procedimentos clínicos realizados por dentistas sempre são necessários.

Concordo plenamente

Concordo

Neutro

Discordo

Discordo plenamente 
20. É possível avaliar a gravidade de um caso de traumatismo dentário exclusivamente por imagens.
- Concordo plenamente
Concordo
Neutro
Discordo
Discordo Plenamente

21. É possível avaliar a gravidade dos casos de traumatismos dentários por meio de imagens associadas a textos descritivos ou mensagens de voz.
Concordo plenamente
Concordo
Neutro
Discordo
Discordo plenamente

22. Profissionais devem receber honorários por consultas e orientações realizadas à distância para pacientes.
Concordo plenamente
Concordo
Neutro
Discordo
Discordo plenamente 
APÊNDICE A- QUESTIONÁRIO

Utilização de recursos da Teleodontologia pelos Odontopediatras do Distrito Federal no atendimento aos Traumatismos Dentários

23. Profissionais devem receber honorários por consultas e orientações realizadas à distância para outros profissionais.

Concordo plenamente

Concordo

Neutro

Discordo

Discordo plenamente

24. O não recebimento de honorários pelas orientações à distância, nos casos de traumatismos dentários, interfere na quantidade e qualidade das informações prestadas pelo profissional.

Concordo plenamente

Concordo

Neutro

Discordo

Discordo plenamente

25. A consulta à distância pode auxiliar no diagnóstico, tratamento ou controle dos casos de traumatismos dentários.

Concordo plenamente

Concordo

C Neutro

Discordo

Discordo Plenamente 
APÊNDICE A- QUESTIONÁRIO

Utilização de recursos da Teleodontologia pelos Odontopediatras do Distrito Federal no atendimento aos Traumatismos Dentários

26. A consulta à distância pode em alguns casos substituir a consulta presencial no diagnóstico, tratamento ou controle dos casos de traumatismos dentários.
- Concordo plenamente
Concordo
Neutro
Discordo
Discordo plenamente

27. Para o atendimento aos casos de traumatismos dentários há necessidade de grande conhecimento técnico-científico envolvendo diversas especialidades odontológicas.

Concordo plenamente

Concordo

Neutro

Discordo

Discordo Plenamente

28. Durante uma consulta à distância informações básicas devem ser repassadas ao profissional consultado para que ele oriente de forma adequada, de acordo com o tipo de traumatismo dentário.
Concordo plenamente
Concordo
Neutro
Discordo
Discordo plenamente 
APÊNDICE A- QUESTIONÁRIO

Utilização de recursos da Teleodontologia pelos Odontopediatras do Distrito Federal no atendimento aos Traumatismos Dentários

29. Uma central de consultas à distância pode auxiliar pacientes e profissionais na resolução de casos de traumatismos dentários.

Concordo plenamente

Concordo

Neutro

Discordo

Discordo Plenamente

30. Baseando-se na descrição de telodontologia acima e na sua prática atual, pode-se considerar que você é um profissional que faz uso das ferramentas da teleodontologia.

Concordo plenamente

Concordo

Neutro

Discordo

Discordo plenamente 


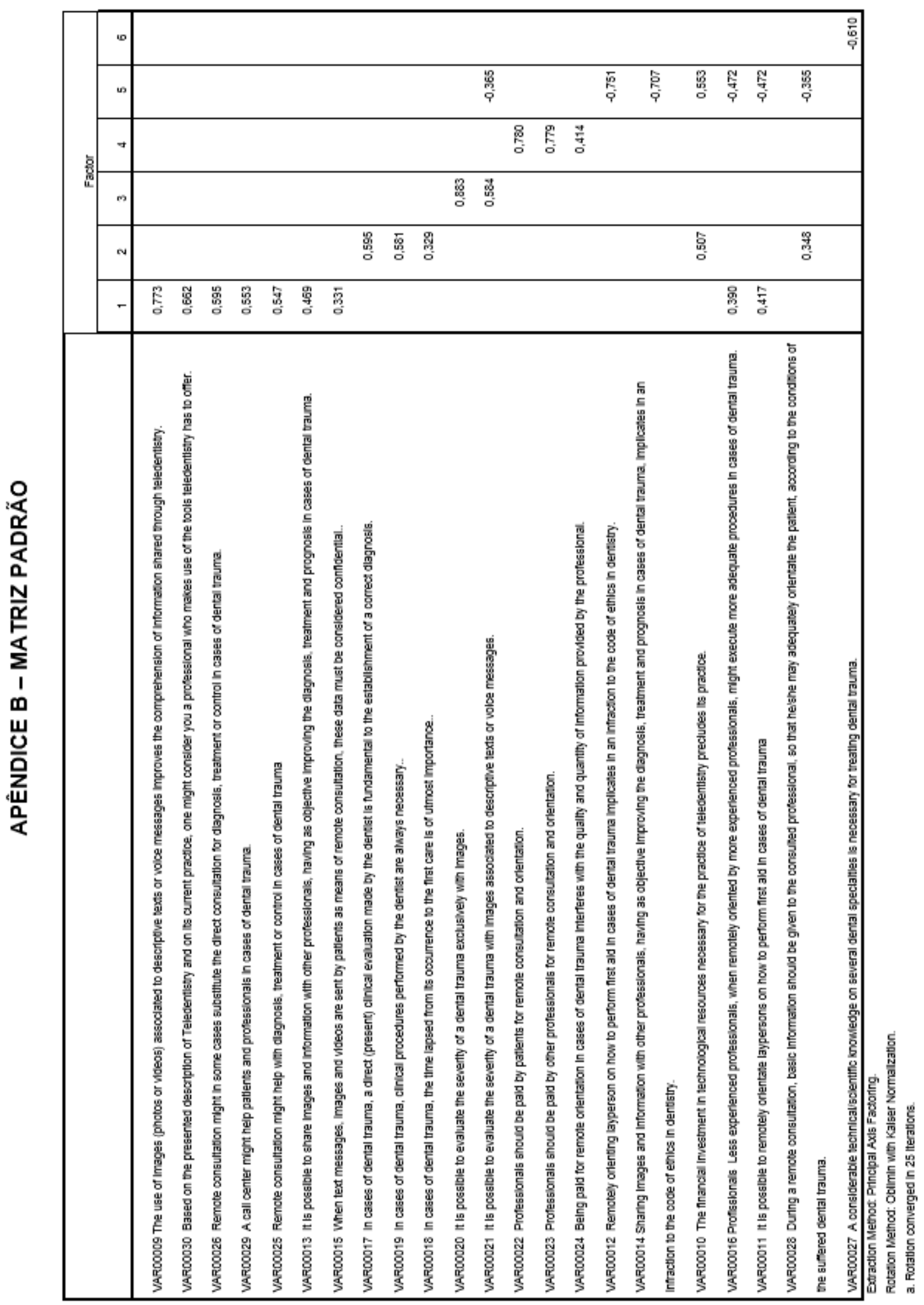




\title{
APÊNDICE C - TERMO DE CONSENTIMENTO LIVRE E ESCLARECIDO - TCLE (ADULTOS)
}

\section{Termo de Consentimento Livre e Esclarecido - TCLE}

O Senhor(a) está sendo convidado(a) a participar do projeto "Utilização de recursos da Teleodontologia no atendimento aos Traumatismos Dentários".

O objetivo desta pesquisa é avaliar o uso de imagens digitais como ferramenta auxiliar no diagnóstico dos Traumatismos Dentários da região ântero-superiores em pacientes atendidos em serviços odontológicos de urgência no Distrito Federal.

$\mathrm{O}$ (a) senhor(a) receberá todos os esclarecimentos necessários antes e no decorrer da pesquisa e lhe asseguramos os cuidados com a proteção com a sua identidade, mantendo rigoroso sigilo de quaisquer informações que permitam identificá-lo(a).

A sua participação será através da permissão do uso das imagens (fotos) realizadas de sua boca e dentes, utilizando uma câmera integrada a um aparelho celular. Serão realizados antes do atendimento odontológico, uma série de nove fotografias digitais, com duração em média cinco minutos para sua execução. As fotografias serão realizadas no mesmo local do atendimento odontológico.

Informamos que o(a) senhor(a) pode se recusar a participar de qualquer procedimento que lhe traga constrangimento, podendo desistir de participar da pesquisa em qualquer momento sem nenhum prejuízo para o(a) senhor(a). A sua participação é voluntária, isto é, não há pagamento por sua colaboração.

Este estudo apresenta risco mínimo de ter sua identidade revelada. No entanto, o(a) senhor(a) tem assegurado o direito a ressarcimento ou indenização no caso de quaisquer danos eventualmente produzidos pela pesquisa.

Os resultados da pesquisa serão divulgados na dissertação de mestrado do pesquisador responsável, podendo ser publicado posteriormente, ficando os dados e materiais utilizados sob a guarda do pesquisador por um período de no mínimo cinco anos, após isso serão destruídos ou mantidos na instituição.

Se o(a) Senhor(a) tiver qualquer dúvida em relação à pesquisa, por favor telefone para: Dr. Rogério de Almeida Geraldino, pelos telefones: (61) 3347-0583 ou 8427-8428. E-mail: rogerio@cabiodontologia.com.br.

Este projeto foi Aprovado pelo Comitê de Ética em Pesquisa da Faculdade de Ciências da Saúde da Universidade de Brasília. As dúvidas com relação à assinatura do TCLE ou os direitos do sujeito da pesquisa podem ser obtidos através do telefone: (61) 3107-1947 ou do e-mail cepfs@unb.br.

Este documento foi elaborado em duas vias, uma ficará com o pesquisador responsável e a outra com o participante da pesquisa.

Brasília, de de

Nome / assinatura 


\title{
APÊNDICE D - TERMO DE CONSENTIMENTO LIVRE E ESCLARECIDO - TCLE (CRIANÇAS E ADOLESCENTES)
}

\author{
$+$ \\ UnB \\ UNIVERSIDADE DE BRASÍLIA \\ FACULDADE DE CIÊNCIAS DA SAÚDE \\ COMITÊ DE ÉTICA EM PESQUISA COM SERES HUMANOS \\ CAMPUS UNIVERSITÁRIO DARCY RIBEIRO \\ BRASÍLIA - DF \\ TELEFONE (061) 3107-1947 \\ E-mail: cepfs@unb.br \\ http://fs.unb.br/cep/
}

\section{Termo de Consentimento Livre e Esclarecido - TCLE}

O menor pelo qual o(a) Senhor(a) é responsável está sendo convidado(a) a participar do projeto "Utilização de recursos da Teleodontologia no atendimento aos Traumatismos Dentários".

O objetivo desta pesquisa é avaliar o uso de imagens digitais como ferramenta auxiliar no diagnóstico dos Traumatismos Dentários da região ântero-superiores em pacientes atendidos em serviços odontológicos de urgência no Distrito Federal.

$\mathrm{O}(\mathrm{a})$ senhor(a) e o(a) menor receberão todos os esclarecimentos necessários antes e no decorrer da pesquisa e lhe asseguramos todos os cuidado com a proteção com a identidade, mantendo o mais rigoroso sigilo de quaisquer informações que permitam identificá-los(as).

A participação do(a) menor será através da permissão do uso das imagens (fotos) realizadas de sua boca e dentes, utilizando uma câmera integrada a um aparelho celular. Serão realizados antes do atendimento odontológico, uma série de nove fotografias digitais, com duração em média cinco minutos para sua execução. As fotografias serão realizadas no mesmo local do atendimento odontológico.

Informamos que o(a) menor pode se recusar a participar de qualquer procedimento que lhe traga constrangimento, podendo desistir de participar da pesquisa em qualquer momento sem nenhum prejuízo para ele ou para o(a) senhor(a). A participação dele(a) é voluntária, isto é, não há pagamento por sua colaboração.

Este estudo apresenta risco mínimo de ter sua identidade revelada. No entanto, o(a) menor tem assegurado o direito a ressarcimento ou indenização no caso de quaisquer danos eventualmente produzidos pela pesquisa.

Os resultados da pesquisa serão divulgados na dissertação de mestrado do pesquisador responsável, podendo ser publicado posteriormente, ficando os dados e materiais utilizados sob a guarda do pesquisador por um período de no mínimo cinco anos, após isso serão destruídos ou mantidos na instituição.

Se o(a) Senhor(a) tiver qualquer dúvida em relação à pesquisa, por favor telefone para: Dr. Rogério de Almeida Geraldino, pelos telefones: (61) 3347-0583 ou 8427-8428. Email: rogerio@cabiodontologia.com.br.

Este projeto foi Aprovado pelo Comitê de Ética em Pesquisa da Faculdade de Ciências da Saúde da Universidade de Brasília. As dúvidas com relação à assinatura do TCLE ou os direitos do sujeito da pesquisa podem ser obtidos através do telefone: (61) 3107-1947 ou do e-mail cepfs@unb.br.

Este documento foi elaborado em duas vias, uma ficará com o pesquisador responsável e a outra com o responsável pelo(a) menor.

Brasília, de de

Nome / assinatura

Rogério de Almeida Geraldino

Pesquisador Responsável 


\title{
APÊNDICE E - TERMO DE ASSENTIMENTO (CRIANÇAS E ADOLESCENTES)
}

\author{
$\psi$ \\ UnB \\ UNIVERSIDADE DE BRASÍLIA \\ FACULDADE DE CIÊNCIAS DA SAÚDE \\ COMITÊ DE ÉTICA EM PESQUISA COM SERES HUMANOS \\ CAMPUS UNIVERSITÁRIO DARCY RIBEIRO \\ BRASÍLIA - DF \\ TELEFONE (061) 3107-1947 \\ E-mail: cepfs@unb.br \\ http://fs.unb.br/cep/
}

\section{TERMO DE ASSENTIMENTO}

Você está sendo convidado(a) como voluntário(a) a participar da pesquisa "Utilização de recursos da Teleodontologia no atendimento aos Traumatismos Dentários". Neste estudo pretendemos avaliar o uso de imagens digitais feitas por celulares para ajudar a reconhecer os Traumatismos Dentários em pacientes que sofreram acidentes e foram atendidos em serviços odontológicos de urgência no Distrito Federal.

O motivo que nos leva a estudar esse assunto é saber se as imagens produzidas por celulares podem ajudar no diagnóstico dos traumatismos dentários.

A sua participação será através da permissão de uso das imagens (fotos) realizadas de sua boca e dentes, utilizando uma câmera integrada a um aparelho celular. Serão realizados antes do atendimento odontológico, uma série de nove fotografias digitais, com duração em média de cinco minutos para sua execução. As fotografias serão realizadas no mesmo local do atendimento odontológico.

Para participar deste estudo, o responsável por você deverá autorizar e assinar um termo de consentimento. Você não terá nenhum custo, nem receberá qualquer vantagem financeira. Você será esclarecido(a) em qualquer aspecto que desejar e estará livre para participar ou recusar-se. O responsável por você poderá retirar o consentimento ou interromper a sua participação a qualquer momento. A sua participação é voluntária e se você se recusar a participar não terá problemas, seu atendimento será normal. Você não será identificado em nenhuma publicação. Este estudo apresenta risco mínimo de ter sua identidade revelada. Entretanto, você tem assegurado o direito a ressarcimento ou indenização no caso de quaisquer danos eventualmente produzidos pela pesquisa.

Os resultados estarão à sua disposição quando finalizados. Seu nome ou as fotos que indique sua participação não será liberado sem a permissão do responsável por você. Os dados e instrumentos utilizados na pesquisa ficarão arquivados com o pesquisador responsável por um período de 5 anos, e após esse tempo serão destruídos. Este termo de consentimento encontra-se impresso em duas vias, sendo que uma cópia será arquivada pelo pesquisador responsável, e a outra será fornecida a você.

Se você tiver qualquer dúvida em relação à pesquisa, por favor peça ao seu responsável que entre em contato por telefone com o Dr. Rogério de Almeida Geraldino, pelos telefones: (61) 3347-0583 ou 8427-8428 ou pelo email: rogerio@cabiodontologia.com.br.

Este projeto foi Aprovado pelo Comitê de Ética em Pesquisa da Faculdade de Ciências da Saúde da Universidade de Brasília. As dúvidas com relação à assinatura do TCLE ou os direitos em relação à pesquisa podem ser obtidos através do telefone: (61) 3107-1947 ou do e-mail cepfs@unb.br.

$\mathrm{Eu}$, portador(a) do documento de Identidade __ (se já tiver documento), fui informado(a) dos objetivos do presente estudo de maneira clara e detalhada e esclareci minhas dúvidas. Sei que a qualquer momento poderei solicitar novas informações, e o meu responsável poderá modificar a decisão de participar se assim o desejar. Tendo o consentimento do meu responsável já assinado, declaro que concordo em participar desse estudo. Recebi uma cópia deste termo assentimento e me foi dada a oportunidade de ler e esclarecer as minhas dúvidas.

Brasília-DF, de de 20 


\section{APÊNDICE F - AVALIADOR(A) PRESENCIAL \\ Formulário para Diagnóstico Provável em casos de Traumatismos Dentários Caso clínico no Examinador presencial}

\begin{tabular}{|c|c|c|c|c|c|c|}
\hline Tipo de Traumatismo dental diagnosticado & $11 / 51$ & $12 / 52$ & $13 / 53$ & $21 / 61$ & $22 / 62$ & $23 / 63$ \\
\hline \multicolumn{7}{|l|}{ Concussão } \\
\hline \multicolumn{7}{|l|}{ Subluxação } \\
\hline \multicolumn{7}{|l|}{ Luxação lateral } \\
\hline \multicolumn{7}{|l|}{ Luxação Intrusiva } \\
\hline \multicolumn{7}{|l|}{ Luxação Extrusiva } \\
\hline \multicolumn{7}{|l|}{ Avulsão } \\
\hline \multicolumn{7}{|l|}{ Trinca de esmalte } \\
\hline \multicolumn{7}{|l|}{ Fratura coronária de Esmalte } \\
\hline \multicolumn{7}{|l|}{ Fratura coronária Esmalte-Dentina } \\
\hline \multicolumn{7}{|l|}{ Fratura coronária Esmalte-Dentina com exposição pulpar } \\
\hline \multicolumn{7}{|l|}{ Fratura coronorradicular } \\
\hline \multicolumn{7}{|l|}{ Fratura coronorradicular com exposição pulpar } \\
\hline \multicolumn{7}{|l|}{ Fratura Radicular } \\
\hline Fratura alveolar & & & & & & \\
\hline
\end{tabular}

\section{Possíveis achados clínicos:}

1. Mobilidade

2. Sangramento sulco gengival

3. Deslocamentos vestibulares ou palatinos

4. Deslocamentos extrusivos/intrusivos

5. Dor à percussão vertical

6. Dor à percussão lateral

7. Alteração de cor (cinza ou amarelo)

8. Fraturas coronárias

9. Exposição pulpar

10. Alterações de cor da gengiva

11. Dor ao estímulo térmico (frio)

12. Dente em erupção parcial

13. Interferência oclusal

14. Laceração/abrasão/contusão de tecidos moles

15. Histórico de traumatismo dentário

\section{Sinais e sintomas:}

Sexo: ( ) Masc. ( ) Fem. Data Nasc. .Tempo decorrido do acidente:

Data: . Dentista Responsável: 


\section{APÊNDICE G - AVALIADOR(A) A DISTÂNCIA \\ Formulário para Diagnóstico Provável em casos de Traumatismos Dentários Caso clínico no Examinador à distância}

\begin{tabular}{|c|c|c|c|c|c|c|}
\hline Tipo de Traumatismo dental diagnosticado & $11 / 51$ & $12 / 52$ & $13 / 53$ & $21 / 61$ & $22 / 62$ & $23 / 63$ \\
\hline \multicolumn{7}{|l|}{ Concussão } \\
\hline \multicolumn{7}{|l|}{ Subluxação } \\
\hline \multicolumn{7}{|l|}{ Luxação lateral } \\
\hline \multicolumn{7}{|l|}{ Luxação Intrusiva } \\
\hline \multicolumn{7}{|l|}{ Luxação Extrusiva } \\
\hline \multicolumn{7}{|l|}{ Avulsão } \\
\hline \multicolumn{7}{|l|}{ Trinca de esmalte } \\
\hline \multicolumn{7}{|l|}{ Fratura coronária de Esmalte } \\
\hline \multicolumn{7}{|l|}{ Fratura coronária Esmalte-Dentina } \\
\hline \multicolumn{7}{|l|}{ Fratura coronária Esmalte-Dentina com exposição pulpar } \\
\hline \multicolumn{7}{|l|}{ Fratura coronorradicular } \\
\hline \multicolumn{7}{|l|}{ Fratura coronorradicular com exposição pulpar } \\
\hline \multicolumn{7}{|l|}{ Fratura Radicular } \\
\hline Fratura alveolar & & & & & & \\
\hline
\end{tabular}

\section{Possíveis achados clínicos:}

1. Mobilidade

2. Sangramento sulco gengival

3. Deslocamentos vestibulares ou palatinos

4. Deslocamentos extrusivos/intrusivos

5. Dor à percussão vertical

6. Dor à percussão lateral

7. Alteração de cor (cinza ou amarelo)

8. Fraturas coronárias

9. Exposição pulpar

10. Alterações de cor da gengiva

11. Dor ao estímulo térmico (frio)

12. Dente em erupção parcial

13. Interferência oclusal

14. Laceração/abrasão/contusão de tecidos moles

15. Histórico de traumatismo dentário

\section{Sinais e sintomas:}

Sexo: ( ) Masc. ( ) Fem. Data Nasc. .Tempo decorrido do acidente:

Data: . Dentista Responsável: 
ANEXO 1 - APROVAÇÃO DO COMITÊ DE ÉTICA

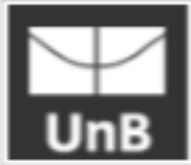

\section{FACULDADE DE CIÊNCIAS DA SAÚDE DA UNIVERSIDADE DE BRASILIA - CEP/FS-UNB}

\section{PARECER CONSUBSTANCIADO DO CEP}

\section{DADOS DO PROJETO DE PESQUISA}

Título da Pesquisa: Utilização de recursos da Teleodontologia no atendimento aos Traumatismos Dentários

Pesquisador: ROGÉRIO DE ALMEIDA GERALDINO

Area Temática:

Versão: 3

CAAE: 24070914.4 .0000 .0030

Instituição Proponente: FACULDADE DE SAÚDE - FS

Patrocinador Principal: Financiamento Próprio

\section{DADOS DO PARECER}

Número do Parecer: 713.602

Data da Relatoria: 09/07/2014

\section{Apresentação do Projeto:}

O traumatismo dentário (TD) ou Traumatismos Dentários (TDs) săo considerados um problema de saúde pública emergente (GUEDES et al., 2010; AMORIM et al., 2011) devido ao crescente aumento dos níveis de violência, do número de acidentes de trânsito e uma maior participação das crianças em atividades esportivas (GLENDOR et al., 1996). Outro argumento que evidencia os TDs, é o decréscimo da prevalência da doença cárie, o que tem permitido um olhar mais ampliado para outras enfermidades bucais. As consequências das injúrias dentárias traumáticas variam desde uma simples fratura do esmalte até a avulsăo dentária (RAOOF et al., 2011). Trauma dental é frequentemente imprevisivel e a avaliaçäo inicial e tratamento de urgência săo essenciais para um bom prognóstico (WONSE et al., 2012). Entretanto, hoje acredita-se que 05 acidentes, incluindo o TD, possa na sua grande maioria ser evitados. A Teleodontologia pode ser definida como a prestação de serviços odontológicos à distância, orientaçôes ou tratamento por meio da tecnologia da informaçăo, substituindo o contato pessoal direto com o paciente envolvido. As aplicaçōes da Teleodontologia podem envolvem registros eletrônicos de pacientes, diagnósticos, sistemas de apoio à decisão clínica e educação do pacientes (KHAN: OMAR, 2013). A Teleodontologia é uma área em expansăo, mas ainda existem algumas barreiras à sua utilizaçăo, principalmente ligadas




ANEXO 1 - APROVAÇÃO DO COMITÊ DE ÉTICA

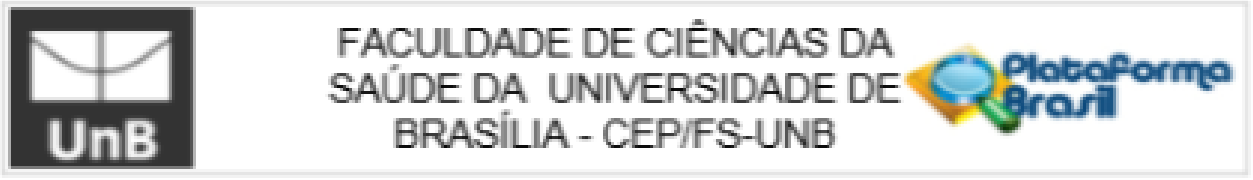

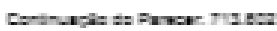

às questíes legais e éficas, tais como confidencialidade das informaçốes odontológicas (BHAMBAL et al. 2010). Pesquisas adicionais săo necessárias para avalar as modalidades ideais, custos e 0 seus possiveis beneficios (NARINO; GHANIM, 2013).

Objetivo da Pesquisa:

Objetivo primário

Avaliar o uso da Teleodontologia como recurso instrumental no atendimento aos casos de TDs.

Objetivo secundário

Identificar a Teleodontologia como recurso ao atendimento de TD na prítica díria do dentista especialista em odontopediatria do Distrito Federal.

Avaliar um sistema de teleodontologia utilizando imagens digitais como ferramenta auxillar no diagnóstico dos TDs da regiảo ântero-superior em pacientes atendidos em serviços odontológicos de urgència no Distrito Federal

Avaliação dos Riscos e Beneficios:

Embora 05 pesquisadores considerem que năo terham identificado prejuizos aos profissionais entrevistados, uma vez que manterâo seu anonimato e que nảo identificaram riscos aos pacientes atendidos pelos serviços de traumatologia dentária, uma vez que o registro fotográfico já é uma condiçăo habitual no atendimento clinico, justificado pela odontologia legal, considerando o disposto no item V, resolução 460/2012 CNSMS caput, toda pesquisa com seres humanos envolve risco em tipos e gradaçōes variados, solioita-se que os pesquisadores explicitem o risco de exposiçăo das identidades dos sujetios tanto no projeto quanto nos respectivos TCLEs indicando como recurso de controle desses riscos o anonimato. Quanto aos beneficios indicam a constataçăo do uso da Teleodontologia, justificará a necessidade de regulamentaģ̃es da nova prásca junto ao Conselho Federal de Odontologia.Os pacientes que participarem da pesquisa, contribuirảo para o avanço na incorporaçăo de novas tecnologias na odontologia. o que poderia melhorar 0 acesso aos serviços de saúde

\section{Comentários e Consideraçōes sobre a Pesquisa:}

Trata-se de um estudo do tipo descritivo transversal, referente à dissertaçăo de Mestrado do Cirurgião Dentista Rogénio de Almeida Geraldino do Programa de Pós-graduaçấo em Ciëncias da Saúde da FS/UnB, sob orientação do Prot. Dr. Júlio César Franco Almeida. A pesquisa consistirả na avaliaçăo quali-quantitativa do processo de validaçảo de uso do sistema de teleodontologia nos casos de traumatismo alvéolo-dentário. O projeto encontra-se distribuido em duas etapas. A primeira uma pesquisa censitária, com a aplicação de

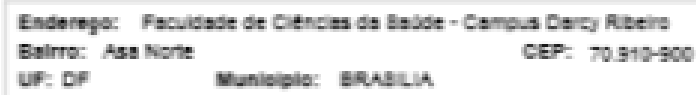




\section{ANEXO 1 - APROVAÇÃO DO COMITÊ DE ÉTICA}

FACULDADE DE CIÊNCIAS DA
SAÚDE DA UNIVERSIDADE DE
BnB Brotoformo
BRASILIA - CEP/FS-UNB

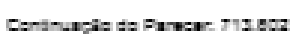

questionário aos 300 especialistas em odontopediatria inscritos no CRO-DF. Será utilizada a ferramenta SurveyMonkey com questionário validado por 05 especialistas em Odontopediatria, e posteriormente enviados por email aos sujeitos da pesquisa. Na segunda etapa seräo realizados atendimentos por demanda espontånea a pacientes portadores de TDs. Os locais de atendimento o serviço de urgência do Hospital Universitário de Brasilia - HuB, e os consultórios particulares do Grupo Odontopediatras 24 horas. Nos pacientes portadores de TDs, amostra 50, por conveniencia, após assinatura TCLEs, seräo realizadas três fotografias digitais extraorais. Nos sujeitos/pacientes haverá, entăo, a realizaçăo de 3 diagnósticos: 1) realizado no atendimento presencial (padrão ouro); 2) realizados à

distância, exclusivamente por imagens; e, 3) também se dará à distância, com imagens e um texto descritivo com dados clínicos (sinais e sintomas) fornecidos pelo profissional que realizou 0 atendimento presencial. Os exames serảo comparados e tratados estatisticamente para validação do método. Como criterios de incluso da $1^{\prime \prime}$ etapa, todos os profissionais

registrados no CRO-DF na especialidade de odontoprdiatria. Como criterio de incluso na $2^{\mathbf{a}}$ etapa, todos os pacientes atendidos nas unidades de trauma alvéolo-dentário independente das idades. $O$ pesquisador submeteu a este CEP a seguinte documentaçăo: 1) Carta de encaminhamento; 2) Folha de rosto; 3) Termo de responsabilidade e compromisso do pesquisador, 4) Termo de ciência de instituiçăo co-participante com assinatura do Superintendente do HUB Prof. Dr. Hervaldo Sampaio Carvalho; 5) Projeto de pesquisa,

acompanhado de cronograma de atividades; 6) Curriculo lattes do pesquisador Rogério de Almeida Geraldino e do orientador do Prof. Dr. Júlio César Franco Almeida; 7) PB informaçôes básicas com planilha de custos e, 8) Termos de Consentimento Livre e esclarecido para profissionais e pacientes. Em segunda submissảo o pesquisador acrescentou; 1) novo projeto básico com correção do cronograma; 2) termo de ciência de co-participante dos consultórios assinados por Rogério de Almeida Geraldino, Ludmila da Silva Costa Marilho, Camila de Sousa e Albuquerque Barbosa; novo TCLE com a correção a respeito do uso de imagem, entretanto, ainda persiste a ausência de indicaçăo explicita de indenização conforme letras $\mathrm{G}$ e $\mathrm{H}$ do item V .3. Em terceira submissăo o pesquisador apresentou o TALE e o TCLE conforme resolução 466/2012. Dessa maneira a documentaçăo apresentada acompanha as determinaçōes da resolução 466/2012 CNS/MS. Os currículos dos pesquisadores săo compativeis com a complexidade do projeto. A planilha de custos é proporcional ao desenvolvimento da pesquisa sendo custeada com recursos próprios. $O$ cronograma de atividades encontra-se adequado ao período de submissắo do projeto a este CEP






\section{ANEXO 1 - APROVAÇÃO DO COMITÊ DE ÉTICA}

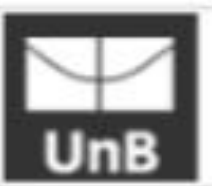

FACULDADE DE CIÊNCIAS DA SAÚDE DA UNIVERSIDADE DE BRASILIA - CEPIFS-UNB

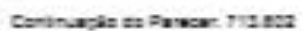

Consideraçōes sobre os Termos de apresentação obrigatória:

O Termo de responsabilidade e compromisso do pesquisador encontra-se satisfatónio conforme as determinaçb̃es da resoluçăo 406/2012 CNS/NS. O Termo de ciência de instituição co-participante com assinatura do Superintendente do HUB Prof. Dr. Hervaldo Sampaio Carvalho encontra-se satisfatb́rio. 0 pesquisador submeteu a este CEP os Termos de Ciência consultónios particulares do Grupo Odontopediatras 24 horas. O TCLE e TALE encontram-se com cabeçalho da Universidade de Brasilia. encontram-se formulados na modalidade

convite. Consta a autorizaçào para o uso de imagem.

Conclusōes ou Pendéncias e Lista de Inadequậôs:

Considerando o atendimento de todas as solicitaçöes deste CEP e em conformidade com a Resoluçâo $408 / 2012$ CNSAMS somos de parecer FAVORÁVEL ao desenvolvimento do presente projeto.

Situaçāo do Parecer:

Aprovado

Necessita Apreciação da CONEP:

Nibo

BRASIUIA, 10 de Juho de 2014

Assinado por:

Marie Togashi

(Coordenador)

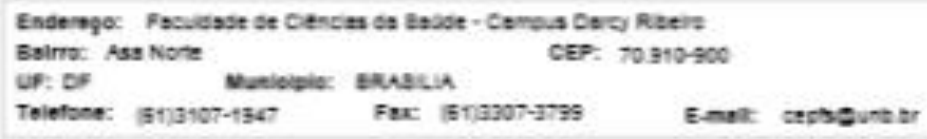


ANEXO 2 - COMPROVANTE DE SUBMISSÃO ARTIGO 1

Rogério Almeida <rogerio@cabiodontologia.com.br>

\section{Dental Traumatology - Manuscript ID DT-05-15-OA-2892}

2 mensagens

dtoffice@qualitynet.net <dtoffice@qualitynet.net>

28 de maio de 2015 22:05

Para: rogerio@cabiodontologia.com.br

28-May-2015

Dear Dr. Geraldino:

Your manuscript entitled "Perceptions and attitudes of pediatric dentists towards the use of teledentistry tools in the management of traumatic dental injuries" has been successfully submitted online. Within the next few days your manuscript will be checked for its compliance with the journal's requirements. If anything does not comply with the Journal's requirements, you will be notified by email that your manuscript has been unsubmitted and returned to your author centre. The email will include detailed explanation of the changes to be made before your manuscript can be resubmitted and considered for publication in the Dental Traumatology

Your manuscript ID is DT-05-15-OA-2892

Please mention the above manuscript ID in all future correspondence. If there are any changes in your street address or e-mail address, please log in to Manuscript Central at https://mc.manuscriptcentral.com/dt and edit your user information as appropriate.

You can also view the status of your manuscript at any time by checking your Author Center after logging in to https://mc.manuscriptcentral.com/dt.

Thank you for submitting your manuscript to the Dental Traumatology.

Sincerely,

Karin Andersson

Dental Traumatology Editorial Office 